\title{
Fuel dynamics after a bark beetle outbreak impacts experimental fuel treatments
}

\author{
Justin S. Crotteau ${ }^{1,2^{*}}$, Christopher R. Keyes ${ }^{1}$, Sharon M. Hood ${ }^{3}$, David L. R. Affleck ${ }^{1}$ and Anna Sala ${ }^{4}$
}

\begin{abstract}
Background: Fuel reduction treatments have been widely implemented across the western US in recent decades for both fire protection and restoration. Although research has demonstrated that combined thinning and burning effectively reduces crown fire potential in the few years immediately following treatment, little research has identified effectiveness of thinning and burning treatments beyond a decade. Furthermore, it is unclear how posttreatment disturbances such as a bark beetle outbreak affect fuel treatment effectiveness.

Results: We evaluated differences in surface and canopy fuel characteristics and potential fire behavior metrics between fuel reduction treatments (no-action or control, burn-only, thin-only, thin+burn) implemented in ponderosa pine (Pinus ponderosa Lawson \& C. Lawson)-Douglas-fir (Pseudotsuga menziesii [Mirb.] Franco)-dominated forests that were subsequently affected by a mountain pine beetle (Dendroctonus ponderosae Hopkins) outbreak after treatment. Experimental units were measured in 2002 (immediately following fuel treatment) and in 2016 (14 years after treatment and at least 4 years following a beetle outbreak). We found that beetle-altered thinning treatments (thin-only and thin +burn combined) had less fuel (i.e., 34\% and 83\% lower fine and coarse woody debris loading, respectively) and lower crown fire potential (i.e., $47 \%$ lower probability of torching and $42 \%$ greater crowning index) than corresponding unthinned treatments (control and burn-only). There was no post-beetle-outbreak effect of burning treatments (burn-only and thin+burn combined) on surface fuel loading, but burning reduced crown fire potential (i.e., 37\% greater crowning index) over unburned units (control and thin-only) 14 years after treatment. Additionally, we determined the relative impacts of fuel treatments and the bark beetle outbreak on fuel and crown fire potential differences and found that bark beetle-caused tree mortality inflated differences between controls and thinned treatments (thin-only and thin+burn) for surface fuel loading and probability of torching, but diminished differences between these treatments for canopy fuel loading, canopy bulk density, and crowning index.
\end{abstract}

Conclusions: Despite the differential effects of bark beetle-caused tree mortality in the treatments, our study suggests that the effects of fuel treatments on mitigating crown fire potential persist even after a stand-transforming insect outbreak, especially when thinning and burning are combined.

Keywords: Dendroctonus ponderosae, disturbance interaction, fire and fire surrogate study, fuel dynamics, mediation analysis, Pinus ponderosa, Pseudotsuga menziesii, treatment longevity

\footnotetext{
* Correspondence: jcrotteau@fs.fed.us

${ }^{1}$ University of Montana, WA Franke College of Forestry and Conservation, 32

Campus Drive, Missoula, Montana 59812, USA

${ }^{2}$ Present address: USDA Forest Service, Pacific Northwest Research Station,

11175 Auke Lake Way, Juneau, Alaska 99801, USA

Full list of author information is available at the end of the article
} 


\section{Resumen}

Antecedentes: Los tratamientos de reducción de combustibles han sido ampliamente usados a través del oeste de los EEUU en décadas recientes, tanto para protección de incendios como en restauración. Aunque las investigaciones han demostrado que la combinación de raleos y quemas prescriptas reducen efectivamente el potencial de tener fuegos de copas por algunos años después de estos tratamientos, pocas investigaciones han identificado la efectividad de los raleos y la posterior quema más allá de una década. Además, es poco claro como disturbios post- tratamientos tales como epidemias del escarabajo de la corteza afectan la efectividad de estos tratamientos.

Resultados: Evaluamos las diferencias en las características de combustibles superficiales y del dosel arbóreo y las propiedades potenciales de parámetros del comportamiento del fuego entre distintos tratamientos de reducción de combustible (ninguna acción o control, quema, raleo, y raleo+quema), implementado en bosques dominados por pino ponderosa (Pinus ponderosa Lawson \& C. Lawson) y pino Oregón (Pseudotsuga menziesii [Mirb.] Franco), que fueron afectados por una epidemia del escarabajo del pino de montaña (Dendroctonus ponderosae Hopkins) después de efectuados estos tratamientos. Las unidades experimentales fueron medidas en 2002 (inmediatamente después de efectuados los tratamientos) y en 2016 (14 años post- tratamientos y al menos 4 años posteriores a la epidemia del escarabajo de montaña). Encontramos que los tratamientos de raleo afectados por el escarabajo de montaña (raleo, y raleo+quema) tenían menos combustible (i.e., 34\% y $83 \%$ menos de combustible fino y restos de troncos muertos en superficie), y menor potencial de fuegos de copas (i.e., 47\% menos probabilidad de coronamiento y $42 \%$ más de índice de coronamiento) que los correspondientes a los tratamientos no raleados (control y solo quema). No hubo otro efecto post- epidemia del escarabajo de montaña en los tratamientos de quema (solo quema y raleo+quema combinados) en los combustibles de superficie, aunque la quema redujo el potencial de coronamiento (i.e., 37\% más de índice de coronamiento) sobre las unidades no quemadas (control y solo raleadas) 14 años después del tratamiento. Adicionalmente, determinamos los impactos relativos de los tratamientos de combustible y la epidemia del escarabajo de montaña en las diferencias entre los combustibles y en el potencial de coronamiento. Encontramos que la mortalidad de árboles causada por el escarabajo de montaña aumentó las diferencias entre el tratamiento de control y los que involucraban tratamientos de raleos (raleo solo y raleo+quema), en lo que hace a la carga de combustible superficial y la probabilidad de coronamiento del fuego, pero disminuyó las diferencias entre esos tratamientos para la carga de combustible del dosel, su densidad aparente, y el índice de coronamiento.

Conclusiones: A pesar de los efectos diferenciales de las causales de muerte de árboles por el escarabajo de montaña en los tratamientos, nuestro estudio sugiere que los efectos de tratamientos de combustibles para mitigar el potencial de coronamiento de fuegos persiste aun después de la transformación de los rodales por la epidemia del escarabajo de montaña, especialmente cuando se combinan los tratamientos de raleos y quemas.

\section{Background}

A major goal of fuel reduction treatments is to mitigate potential wildfire behavior, especially to reduce the probability of crown fires in forests (Reinhardt et al. 2008). Many restoration efforts in fire-prone ecosystems also include fuel reduction strategies to reverse the effects of fire exclusion on forest fuels, structure, and composition (Brown et al. 2004, Fulé et al. 2012). However, treatment effects are ephemeral, as forest development in the years following treatment may compromise the effectiveness of treatments to mitigate crown fire behavior (Keyes and Varner 2006, Affleck et al. 2012, Tinkham et al. 2016). Wildland fire is not the only disturbance in many forests (Bebi et al. 2003, Bigler et al. 2005, Raffa et al. 2008, Kolb et al. 2016); fuel treatments may also interact with insect outbreaks and droughts, for example. Understanding how fuel treatments develop with time and in response to an exogenous disturbance such as a beetle outbreak has important implications for fuel treatment effectiveness and longevity in light of management objectives.

Fuel treatments in forests are often designed to decrease crown fire behavior (i.e., propensity for crown fire ignition or spread) by reducing canopy and surface fuels, and increase resistance to fire (i.e, overstory survival) by favoring fire-tolerant species and removing competition. Fire exclusion and canopy ingrowth over the past century have elevated surface and canopy fuel loading in the western US (Parsons and DeBenedetti 1979, Covington and Moore 1994, Keeling et al. 2006). Increased surface and canopy fuel loading in conjunction with a warmer and drier climate have caused wildfires to increase in size and frequency, resulting in greater suppression costs to protect resources (Westerling et al. 2006, Flannigan et al. 2009, Miller et al. 2009). Crown fires threaten human safety and property, and, in forest types where 
crown fire is uncharacteristic, it also threatens ecological resilience (Savage and Nystrom Mast 2005). Fuel reduction is a proactive silvicultural treatment that alters potential fire behavior by removing and modifying fuels to encourage low-severity (low overstory mortality) surface fire instead of high-severity (high overstory mortality) crown fire. Fuel treatments are typically designed to reduce surface fuel loading and canopy densities; increase heights to canopy base; and retain large, fire resistant trees (Agee and Skinner 2005, Hessburg et al. 2015). Although these goals can be attained with various silvicultural techniques, thinning and burning are the most typical means of fuel reduction. The relative effectiveness of thinning and burning to reduce crown fire behavior has been thoroughly studied immediately after treatment (Stephens and Moghaddas 2005, Harrington et al. 2007, Stephens et al. 2009, Fulé et al. 2012, McIver et al. 2012), generally highlighting that burning reduces surface fuels, thinning improves forest structure, and the combination of the two best reduces crown fire potential.

However, fuel treatments are only temporarily effective (Reinhardt et al. 2008, Martinson and Omi 2013). As treated areas age, regeneration, ingrowth, and residual trees grow into open space and increase surface and canopy fuel loading, causing concomitant increases in crown fire potential (Keyes and O'Hara 2002, Keyes and Varner 2006, Affleck et al. 2012). Although stimulated growth and regeneration are expected to follow treatment because of release from competition, it is still unclear how long treatments remain effective. Studies have identified that fuel treatments may be effective for a decade following treatment (Finney et al. 2005, Fernandes 2009, Jain et al. 2012, Stephens et al. 2012), but evidence beyond a decade is scant (though simulated by Tinkham et al. 2016). Understanding of treatment longevity is especially important when logistics and economics limit successive treatments.

Fire exclusion, past management actions, and warming climate have increased probability of crown fire in the West, but they have also been attributed to abetting recent insect outbreaks (Raffa et al. 2008, Bentz et al. 2010). Recent bark beetle outbreaks in the late 1990s to 2012 have profoundly affected several forest types, killing trees over millions of hectares in western US forests (Hicke et al. 2016). Wildfire in beetle-impacted forests is a primary concern for managers because beetle-killed trees alter canopy and surface fuel profiles (Page and Jenkins 2007, Hicke et al. 2012), as foliage on killed trees transitions from green to red to gray phases on the tree, then progressively falls to the forest floor with accompanying limbs and stems (British Colombia Ministry of
Forests 2004, Donato et al. 2013). The impact of beetle-caused tree mortality on potential fire behavior in unmanaged forest landscapes has been a controversial topic (Jenkins et al. 2008, 2014; Simard et al. 2011; Harvey et al. 2013; Hart et al. 2015; Kane et al. 2017).

Bark beetle outbreaks can also directly impact fuel treatments, further altering the fuel profile and fire hazard. The interactions between fuel treatments and beetle outbreaks remain largely uncharacterized. A few studies have identified that fuel treatments may moderate beetle-caused mortality (Fettig et al. 2010, Jenkins et al. 2014, Hood et al. 2016). Conversely, beetle-caused tree mortality may compromise fuel treatment effectiveness by altering surface fuel loading and vegetative competition, depending on time since outbreak initiation. In unmanaged units with beetle-killed trees that have lost their needles (i.e., gray phase), active crown fire behavior and torching probability may be reduced because of altered canopy fuel attributes (Simard et al. 2011), similar to a fuel treatment. But beetle-caused mortality eventually adds fuel to the surface profile, and can thereby increase surface flame lengths, spotting, and residence times, exacerbating crown fire potential in surviving trees (Moran and Cochrane 2012, Jenkins et al. 2014). In treated units that densify and become more prone to crown fire over time, bark beetle-caused mortality may either maintain fuel treatment effectiveness by prolonging the duration of low canopy fuel loading and reducing canopy connectivity, or it may render treatments useless to their original objective by increasing surface fire behavior and probability of torching. Knowledge of fuels and potential crown fire behavior between treated and untreated units is valuable for safety assessment, inventory, and planning, as well as for determining resilience of actively managed units to subsequent disturbance.

The purpose of this study is to understand how silvicultural fuel reduction and a subsequent bark beetle outbreak influence fuel and the potential for crown fire. This study is distinct because it examines fuel treatments that were tested by a beetle outbreak with high levels of tree mortality rather than by low, endemic levels of bark beetle-caused tree mortality. We utilized the northern Rocky Mountains study site of the Fire and Fire Surrogate Study (McIver and Weatherspoon 2010) as a balanced experimental design to contrast fuel treatments (no-action control, burn-only, thin-only, thin+burn) in a (Pinus ponderosa Lawson \& C. Lawson)-Douglas-fir (Pseudotsuga menziesii [Mirb.] Franco)-dominated forest. Treatments were fully implemented by 2002 , at least four years before a widespread mountain pine beetle (MPB; Dendroctonus ponderosae Hopkins) outbreak that overlapped all experimental units. We analyzed surface 
and canopy fuels data from 14 years after silvicultural treatment and at least 4 years after an MPB outbreak, with the specific objective to determine temporal effects of the combined silviculture and MPB outbreak on surface and canopy fuel characteristics. As a follow-up demonstration, we used an industry standard modeling approach (i.e., using the Fire and Fuels Extension to the Forest Vegetation Simulator [FFE-FVS] to predict crown fire potential given post-treatment conditions. Our final objective was to determine the individual effects of silvicultural treatment and the MPB outbreak on surface and canopy fuel characteristics and crown fire potential. This study uniquely showcases the impact that time and beetle outbreak have on restorative fuel treatments, demonstrating how beetle-caused mortality interacts with the development of fuel characteristics and crown fire potential in treated versus untreated units.

\section{Methods}

\section{Study site}

This study was conducted at the University of Montana's Lubrecht Experimental Forest $\left(46^{\circ} 53^{\prime} \mathrm{N}, 113^{\circ} 26^{\prime} \mathrm{W}\right)$, an 11300 ha forest in western Montana's Blackfoot River drainage of the Garnet Range, USA. Study sites ranged in elevation from 1230 to $1388 \mathrm{~m}$ ASL, and were composed of Pseudotsuga menziesii-Vaccinium caespitosum Michx. and Pseudotsuga menziesii-Spiraea betulifolia Pall. habitat types (Pfister et al. 1977). This forest was generally composed of second-growth ponderosa pine (Pinus ponderosa Lawson \& C. Lawson var. scopulorum Engelm.), Douglas-fir (Pseudotsuga menziesii [Mirb.] Franco var. glauca [Beissn.] Franco), with western larch (Larix occidentalis Nutt.) regenerated from heavy cutting in the early twentieth century. Soils are fine or clayey-skeletal, mixed, Typic Eutroboralfs, as well as loamy-skeletal, mixed, frigid, Udic Ustochrepts (Nimlos 1986).

Climate in this study area is maritime-continental. Annual precipitation is approximately $460 \mathrm{~mm}$ (PRISM Climate Group, Oregon State University, http://prism.oregonstate.edu), nearly half of which falls as snow. Mean temperatures range from $-6{ }^{\circ} \mathrm{C}$ in December and January to $17{ }^{\circ} \mathrm{C}$ in July and August. Average plant growing season is between 60 and 90 days. Historic fire frequency at Lubrecht prior to the twentieth century ranged from 2 to 14 years, with a mean composite fire return interval of 7 years (Grissino-Mayer et al. 2006).

\section{Silvicultural activities and MPB "treatment"}

A portion of the Lubrecht Experimental Forest was selected as a site for the Fire and Fire Surrogate Study, a multidisciplinary research project that aimed to quantify the short-term effects of restorative fuel treatments in frequent-fire forests across the US (McIver and Weatherspoon 2010, Weatherspoon 2000). The study provided a framework to examine the effects of common fuel treatments on treatment longevity, fuel development, and potential fire behavior. Treatments were implemented in each of three blocks of approximately 36 ha (9 ha per treatment unit), using a randomized factorial design: two levels of thinning (thinned and unthinned) by two levels of prescribed burning (burned and unburned), for a total of four treatment levels (no-action control, burn-only, thin-only, thin+burn), with one treatment replicate per block. Prescription intensity was designed to maintain $80 \%$ overstory tree survival given a wildfire during 80th percentile weather conditions (Weatherspoon 2000). Units were cut in 2001 and burned in 2002, creating twelve 9 ha experimental units. The silvicultural cutting prescription was a combined low thinning and improvement cut to a residual basal area of $11.5 \mathrm{~m}^{2} \mathrm{ha}^{-1}$, favoring retention of ponderosa pine and western larch over Douglas-fir (although Douglas-fir maintained a significant presence in residual overstories; Metlen and Fiedler 2006). Burning treatments were spring burns with wind speeds less than $13 \mathrm{~km} \mathrm{~h}^{-1}$. Burns were generally low severity, with pockets of high severity in two of the thin+burn treatments. Fiedler et al. (2010) analyzed treatment effect on stand structure and short-term growth, and Stephens et al. (2009) summarized short-term woody fuel and potential fire behavior responses to treatment across western Fire and Fire Surrogate sites.

Approximately four growing seasons after treatment, a regional MPB outbreak in Montana began affecting all experimental blocks in the study (Gannon and Sontag 2010). Beetle-caused overstory mortality levels were high in the control and burn-only units from 2006 to 2012 (Hood et al. 2016), leading to comparable live ponderosa pine basal area across all treatments. After the outbreak, fuel loading, crown fire potential, productivity, and stand dynamics were no longer a pure effect of fuel treatments, but rather of the combination of fuel treatments and beetle-caused tree mortality. This beetle outbreak was an opportunity to assess a novel but increasingly common condition in the West: fuel treatment followed by a MPB outbreak. Therefore, the meaning of "treatment" in this study changes with measurement year. Before the MPB outbreak (prior to 2006), "treatment" refers to the silvicultural fuel treatment. After the MPB outbreak, "treatment" refers to the combination of fuel treatment and MPB-caused tree mortality.

\section{Field methods}

Live trees were measured twice on permanently monumented plots in the Fire and Fire Surrogate Study. Trees were initially measured the year after treatment (measured in 1999 for control, 2001 for thin-only, 2002 for burn-only and thin+burn) on 10 randomly selected plot locations from 36 systematically located grid points 
within each treatment unit, for a total of 120 plots (Metlen and Fiedler 2006). Mature trees were measured on 0.04 ha circular subplots; for each mature tree with a diameter at breast height $(\mathrm{dbh} ; 1.37 \mathrm{~m})$ greater than $10.16 \mathrm{~cm}$, species, dbh, and total height were recorded. Height to the base of live crown was recorded for all "leave" trees according to the silvicultural prescription (i.e., all trees retained in the thin-only and thin+burn treatments, but only a similar subset of trees in the control and burn-only). Height to the base of live crown was estimated based upon the average branch height of the compacted lower limit of the crown (US Forest Service 2005). Trees smaller than $10.16 \mathrm{~cm}$ dbh but taller than $1.37 \mathrm{~m}$ were measured on five $100 \mathrm{~m}^{2}$ subplots; trees between $0.10 \mathrm{~m}$ and $1.37 \mathrm{~m}$ tall were measured on twenty $1 \mathrm{~m}^{2}$ subplots. Mature trees were re-measured in 2014, and trees smaller than $10.16 \mathrm{~cm} \mathrm{dbh}$ were re-measured in 2016 using the protocol outlined above.

Dead surface fuel loading was first measured the year after treatment (same years as above: 1999 for control, 2001 for thin-only, 2002 for burn-only and thin+burn) using a mixture of planar intercept and destructive sampling. A modified Brown's (1974) protocol was used to quantify 1 -h (woody material $<0.64 \mathrm{~cm}$ diameter), $10-\mathrm{h}$ $(0.64 \mathrm{~cm} \leq$ diameter $<2.54 \mathrm{~cm}), 100$-h $(2.54 \mathrm{~cm} \leq$ diameter $<7.62 \mathrm{~cm}$ ), and $1000-\mathrm{h}+($ diameter $\geq 7.62 \mathrm{~cm})$ timelag classes. On each of the 36 grid points, two $15.2 \mathrm{~m}$ transects were established; 1 - $\mathrm{h}$ and 10 -h fuels were tallied for $1.8 \mathrm{~m}$ of the length, 100-h fuels were tallied for $3.7 \mathrm{~m}$, and $1000-\mathrm{h}+$ fuel diameters were recorded along the entire transect lengths. Duff and litter depths were each measured along transects at $4.6 \mathrm{~m}$ and $10.7 \mathrm{~m}$ from plot center. In the thin-only and thin+burn treatments, 1-h, 10-h, litter, and duff materials were not measured along transects but destructively sampled on two $1 \mathrm{~m}^{2}$ quadrats. These materials were taken to the lab, oven dried, and weighed to determine loading by fuel component type. In 2016, we re-measured dead surface fuels using the original modified Brown's transects for all 36 grid points in all of the treatment units.

For simplicity's sake in this paper, the datasets will be referred to by the last year of measurement. Namely, "2002" for the collective immediate post-treatment dataset, and "2016" for the post-beetle-outbreak dataset. By the time of final measurement, units were in the post-epidemic, leaf-off, gray phase of the MPB rotation (Jenkins et al. 2008).

In addition to the 2002 and 2016 datasets, we supplemented our dataset with data measured and analyzed by Hood et al. (2016). Using the same measurement points described above, they measured MPB-caused tree mortality to the overstory ( $\mathrm{dbh}>10.16 \mathrm{~cm}$ ) between 2006 and 2012. We augmented our dataset with their data on plot-scale MPB outbreak severity (overstory stems ha ${ }^{-1}$ ).

\section{Analytical and statistical methods}

We calculated dead downed woody debris loading (Mg ha ${ }^{-1}$ ) according to Brown (1974), and used site-specific depth-to-loading regressions to calculate litter and duff loading $\left(\mathrm{Mg} \mathrm{ha}^{-1}\right)$ (M. Harrington, retired, USDA Forest Service, Missoula, Montana, USA, unpublished data). Dead downed woody fuel loading were grouped into two pools for analysis: fine woody debris (FWD) was composed of fuel less than $7.62 \mathrm{~cm}$ diameter (1-h, 10-h, and 100-h); coarse woody debris (CWD) was composed of sound fuel greater than or equal to $7.62 \mathrm{~cm}$ diameter $(1000-\mathrm{h})$. Litter and duff layers (LD) were combined for analysis.

Surface fuels data and measured tree data were input into FFE-FVS (Dixon 2002, Rebain 2010) to calculate plot-scale canopy fuel characteristics and potential fire behavior for our two measurement years $(2002,2016)$. We estimated fire behavior using FFE-FVS methods, whereby measured dead fuel loadings are keyed to Albini's (1976) 13 original fire behavior fuel models, and the FFE-FVS algorithm selects and weights predicted fire behavior from one to two most similar models (Rebain 2010). This default FFE-FVS method produces consistent results to predictions based entirely on user-inputted, customized fire behavior fuel models in FFE-FVS (Noonan-Wright et al. 2014). Potential fire behavior was based on FFE-FVS's default "severe" fire weather scenario (4\% 10-h fuel moisture, $21.1{ }^{\circ} \mathrm{C}$ ambient temperature, and $32.2 \mathrm{~km} \mathrm{~h}^{-1}$ wind speed at $6.1 \mathrm{~m}$ ) instead of percentile (e.g., 80th or 95th) fire weather conditions to provide standardized analysis. Output gathered from FFE-FVS FUELOUT and POTFIRE reports included canopy fuel loading ( $\mathrm{CF} ; \mathrm{Mg} \mathrm{ha}^{-1}$ ), canopy base height $(\mathrm{CBH} ; \mathrm{m})$, canopy bulk density $\left(\mathrm{CBD} ; \mathrm{kg} \mathrm{m}^{-3}\right)$, potential fire behavior (fire type and surface flame length, $\mathrm{m}$ ), and crown fire potential (probability of torching, PT, $\%$; and crowning index, $\mathrm{CI}, \mathrm{km} \mathrm{h}^{-1}$ ) calculations (see Rebain 2010 for further variable descriptions). We note that the CF loading from the FUELOUT report includes foliage plus branchwood $<7.62 \mathrm{~cm}$ diameter, but FFE-FVS only uses foliage plus half of all materials $<0.64 \mathrm{~cm}$ to calculate CBH and CBD (Rebain 2010).

We recognize that fire prediction models such as FFE-FVS have shortcomings and are simplified representations of actual fuel and weather conditions, especially in bark beetle-impacted forests. Cruz and Alexander (2010) discussed these limitations and found that models typically underpredict fire rate of spread in the forest canopy, and Fernandes (2009) identified that simulation for treatment comparison may produce conflicting results with actual fire behavior. There is no universally accepted alternative to modeling potential fire behavior over large spatial extents, although some researchers have developed empirical crown fire transition models with coarse data inputs (e.g., Cruz et al. 2005) or novel 
approaches to address FFE-FVS's shortcomings (e.g., Nelson et al. 2017). Computational fluid dynamics models have been used to examine potential fire behavior in beetle-impacted forests (Sieg et al. 2017), but these models are not feasible to use on the large, 9 ha treatment units. Despite these shortcomings, FFE-FVS is the standard fuel and fire assessment tool used by vegetation managers, planners, and researchers because it extends fuels data to more meaningful management objectives. Therefore, we used FFE-FVS as a tool to demonstrate treatment-specific outcomes for mitigating fire hazard as it is commonly assessed and given model assumptions. This is a useful means for contrasting treatment alternatives (Johnson et al. 2011); however, we caution users that these predictions may not reflect actual fire behavior, a critical consideration for actual management applications.

We used nested ANOVA to investigate treatment influence on eight fuel and crown fire potential response variables in 2002 and 2016. In this study, plot is nested within experimental unit, which is nested within block. We performed this analysis using the anova.lme function in R's nlme package (Pinheiro et al. 2016, R Core Team 2016). ANOVA models had the form:

$$
\hat{y}_{\mathrm{ijkl}}=\mu+\alpha_{\mathrm{i}}+\beta_{\mathrm{j}} \times \gamma_{\mathrm{k}}+\varepsilon_{\mathrm{ijk}}+\delta_{\mathrm{ijkl}}
$$

where $\hat{y}$ is the plot-scale response variable (2002 and 2016 FWD loading, CWD loading, LD loading, CF loading, $\mathrm{CBH}, \mathrm{CBD}, \mathrm{PT}$, and $\mathrm{CI}), \mu$ is the grand mean, $\alpha_{\mathrm{i}}$ is the block effect (levels 1 to 3 ), $\beta_{\mathrm{j}}$ is the prescribed burn effect (levels not burned and burned), $\gamma_{\mathrm{k}}$ is the thinning effect (levels not thinned and thinned), $\varepsilon_{\mathrm{ijk}}$ is the experimental unit error term, and $\delta_{\mathrm{ijk}}$ is the residual error term associated with plots. Although the block effect would ideally be treated as a random effect, we considered it a fixed effect in this model because there were only three factor levels; therefore, only experimental unit was treated as a random effect.

Next, we used linear mixed effects regression to determine the effect that treatment has on the development of fuel loading and crown fire potential over time (i.e., change in value from 2002 to 2016) using the lme function in nlme. Regression models had the same structure as the nested ANOVA model, except that $\hat{y}$ is the change in plot-scale response variable (FWD, CWD, LD, CF, CBH, CBD, PT, and CI) from 2002 to 2016.

Finally, we conducted mediation analyses to parse out the effects of silvicultural manipulation and the MPB outbreak on fuel and crown fire potential metrics. Mediation analysis allows insight into direct treatment effects and the indirect effects mediated by MPB, as, by 2016, the fuel complex in the treatments was a function of both the fuel treatment and the MPB outbreak. The goal was to characterize the direct effect of the silvicultural treatments $(X)$ on eight different 2016 fuel and crown fire potential metrics $(Y)$, the indirect effect of the treatments on the metrics as mediated by the outbreak $(M)$, and the total effect of the treatments on the metrics given mediation by the outbreak (Fig. 1; Baron and Kenny 1986, MacKinnon et al. 2007). Coefficients are derived by fitting two statistical models: $Y=f(X, M)$, and $M=f(X)$. The direct effect is quantified as the regression coefficient of the relationship between $X$ and $Y$ (leg $c$ of Fig. 1), the indirect effect is quantified as the product of the relationships between $X$ and $M$ (leg $a$ of Fig. 1) and $M$ and $Y$ (leg $b$ of Fig. 1), while the total effect is the sum of direct and indirect effects. We determined the relationships $a, b$, and $c$ using linear mixed effects regression with the same nesting structure characterized in our ANOVA models. Since we wanted to determine the effect that treatment had on mediation, we contrasted each of the active treatment effects with the

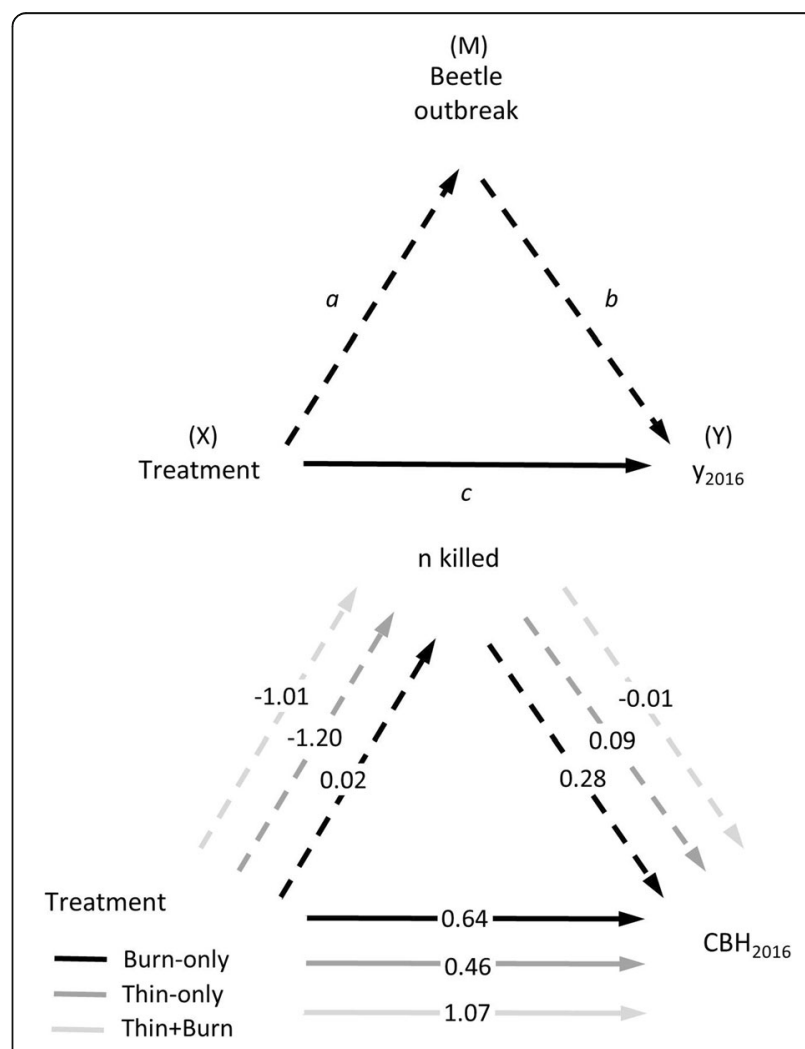

Fig. 1 Conceptual diagram of mediation analysis testing the effect of fuel treatment (versus control) on fuel and crown fire potential as mediated by mountain pine beetle outbreak in the northern Rocky Mountains' Fire and Fire Surrogate Study, 2002 to 2016. Upper panel illustrates overall conceptual framework, with the direct effect as the solid arrow and the indirect effect represented by the dashed-arrow pathway. As an example, the lower panel illustrates regression coefficients linking treatment (Burn-only, Thin-only, Thin+Burn) to canopy base height $\left(\mathrm{CBH}_{2016}\right)$ with the number of trees killed by mountain pine beetles (n killed) representing outbreak severity. 
control (i.e., burn-only vs. control, thin-only vs. control, thin+burn vs. control). All variables were standardized for interpretation of effect size across fuel and crown fire potential metrics, with effect sizes near zero meaning no difference from the control treatment. The bottom panel of Fig. 1 illustrates standardized coefficients for $\mathrm{CBH}$ as an example. We utilized a non-parametric bootstrap resampling routine ( $N=1000$ replications) to determine if direct, indirect, and total effects were significantly different from zero.

In all analyses, treatment effects were considered to have strong evidence of significance at the $95 \%$ confidence level, and marginal evidence of significance at the $90 \%$ level. We inspected residuals from nested ANOVA and linear mixed effects regression models of response state and change for constant variance across treatments using Levene's test of homoscedasticity. When residuals were heteroscedastic, we applied treatment level variance functions using R's varIdent function. Furthermore, we applied square root transformations on responses that showed increasing residual variance with predicted values.

When expedient for summarizing broad patterns and concise interpretation, we grouped treatments according to the crossed factorial design nomenclature. Thinned or thinning refers to thin-only and thin+burn treatments, while unthinned refers to control and burn-only. Burned or burning refers to burn-only and thin+burn treatments, while unburned refers to control and thin-only.

\section{Results}

Thinning was the dominant influence on overstory stand structure and development across measurement years (Table 1), influencing the fuel and fire behavior responses in this study. Thinned units had $67 \%$ lower stem densities than unthinned units in 2002 (79\% and 60\% lower by basal area and stand density index, respectively), but all density metrics were more similar across treatments by 2016. Although differences between thinned and unthinned units in stem density, basal area, and stand density index abated over time by $33 \%, 63 \%$, and $54 \%$, respectively, the contrast between thinned and unthinned quadratic mean diameters increased by $161 \%$ over the measurement period as large trees in the unthinned units were killed by MPB.

\section{Surface fuel loading}

Treatment effect on FWD loading in 2002 (the year following silvicultural treatment) followed an expected pattern (Fig. 2). Burning, thinning, and their interaction all had significant effects on FWD (Table 2; $P \leq 0.024$ ). Burning reduced FWD loading by $63 \%$ (compared to unburned) and thinning increased FWD loading by $250 \%$ (compared to unthinned). In 2016 (at least 4 years following MPB-caused mortality), only thinning had a significant effect, with $34 \%$ less FWD in thinned than unthinned treatments (Table 2; $P=0.028$ ). Whereas in 2002, thin+burn and control loading were no different, in 2016 these two were the only individual treatments that were statistically distinct (Fig. 2). Unthinned units significantly accumulated fuel between 2002 and 2016 (Table 3; $P \leq 0.007$ ), but FWD in the thin-only treatment decreased $(P=0.010)$ and did not change in the thin +burn treatment $(P=0.490)$.

CWD loading was similar across treatments in 2002 (Fig. 2; Table 2), but by 2016, CWD loading was lower in thinned than unthinned treatments (Table 2; $P=0.002$ ). Variability of CWD loading among control units (i.e., standard deviation) was 15 times greater than treated units because of one unit with particularly high CWD loading. Overall, thinned treatment CWD loading was $83 \%$ less than the unthinned treatments. Similar to trends observed in FWD dynamics, unthinned treatments accumulated CWD from 2002 to 2016 (Table 3; $P \leq 0.057)$, whereas CWD in the thin-only treatment reduced over time (Table 3; $P=0.015$ ) and the thin+burn treatment did not change $(P=0.601)$.

Table 1 Mean (and standard error) stand structure metrics by treatment following the Fire and Fire Surrogate Study's fuel treatments in 2002 (immediately after treatment) and in 2016 (following the 2005 to 2012 regional mountain pine beetle outbreak). Stand density index was calculated according to Reineke (1933), equivalent to $25.4 \mathrm{~cm}$ trees per hectare

\begin{tabular}{llllll}
\hline Year & Treatment & $\begin{array}{l}\text { Density } \\
\left(\text { stems ha }{ }^{-1}\right)\end{array}$ & $\begin{array}{l}\text { Basal area } \\
\left(\mathrm{m}^{2} \mathrm{ha}^{-1}\right)\end{array}$ & $\begin{array}{l}\text { Stand density } \\
\text { index } \\
\text { (metric) }\end{array}$ & $\begin{array}{l}\text { Quadratic mean } \\
\text { diameter } \\
(\mathrm{cm})\end{array}$ \\
\hline 2002 & Control & $322(60)$ & $23.1(5.7)$ & $420(99)$ & $31.1(1.5)$ \\
2002 & Burn-only & $304(53)$ & $20.8(2.7)$ & $384(51)$ & $31.2(1.0)$ \\
2002 & Thin-only & $111(11)$ & $9.7(0.4)$ & $170(8)$ & $33.4(0.5)$ \\
2002 & Thin+Burn & $94(12)$ & $8.8(1.2)$ & $339(22)$ & $33.4(0.9)$ \\
2016 & Control & $323(60)$ & $17.8(5.1)$ & $328(49)$ & $26.7(1.9)$ \\
2016 & Burn-only & $291(43)$ & $17.5(2.9)$ & $265(11)$ & $3.9(2.4)$ \\
2016 & Thin-only & $188(27)$ & $14.9(0.4)$ & $181(15)$ & $33.4(2.1)$ \\
2016 & Thin+Burn & $99(13)$ & & & $33.0(1.5)$ \\
\hline
\end{tabular}



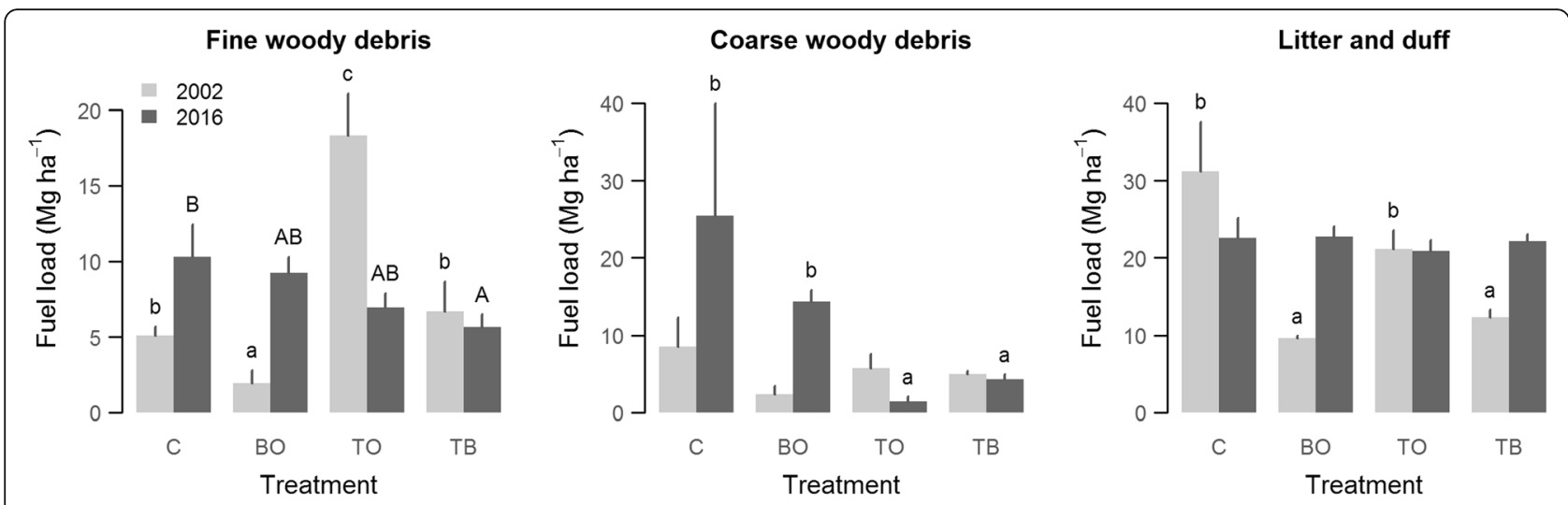

Fig. 2 Surface fuel loads (mean and standard error) by treatment following the northern Rocky Mountains' Fire and Fire Surrogate Study's fuel treatments in 2002 (immediately after treatment) and in 2016 (following the 2005 to 2012 regional mountain pine beetle outbreak). C=Control, $\mathrm{BO}=$ Burn-only, $\mathrm{TO}=$ Thin-only, $\mathrm{TB}=$ Thin+Burn. Fine woody debris loading includes surface wood $<7.62 \mathrm{~cm}$ diameter; coarse woody debris loading includes sound surface wood $\geq 7.62 \mathrm{~cm}$ diameter. Letters above bars denote pairwise differences between treatments (lowercase $=2002$ differences, uppercase $=2016$ differences); letters are not shown when ANOVA tests were not significant

LD loading varied by treatment in 2002 (Fig. 2; Table 2). Loads were $59 \%$ lower in burned treatments than unburned treatments $(P=0.007)$. Although ANOVA results indicated a significant burning and thinning interaction $(P=0.038)$, pairwise comparisons show LD loading assembles into two main treatment groups: burned and unburned. In 2016, LD loading did not vary by treatment (Table 2). Burned treatments significantly accumulated LD loading between 2002 and 2016 (Table 3; $P<0.006$ ), but LD in unburned treatments either decreased (control; $P=0.083)$ or did not change $(P=0.9288)$.

\section{Canopy fuel characteristics}

CF loading differed by thinning in 2002 (Fig. 3; Table 2). The immediate effect of thinning was a $58 \%$ reduction in CF versus the unthinned treatments $(P=0.001)$. In 2016, there was slight evidence of both thinning and burning effects (Table 2; P of 0.096 and 0.060 , respectively). These effects were relatively minor on their own, but when combined, caused the thin+burn treatment to have $43 \%$ less CF than the control. Thinned treatment CF loading increased between 2002 and $2016(P \leq 0.018)$, but unthinned treatment loading decreased $(P \leq 0.049)$.

$\mathrm{CBH}$ in 2002 varied due to thinning (Fig. 3; Table 2), whereby mean $\mathrm{CBHs}$ were $130 \%$ higher in thinned treatments than unthinned $(P<0.001)$. By 2016, CBH varied by both burning and thinning (Table 2). Burned treatments were associated with $105 \%$ greater $\mathrm{CBHs}$ than unburned $(P=0.008)$, and thinned treatments had $79 \%$ greater $\mathrm{CBHs}$ than unthinned treatments $(P=0.008)$. There was slight evidence that interaction amplified these effects $(P=0.094)$ such that the thin+burn treatment was 3.2 times greater than the control. $\mathrm{CBH}$ dropped significantly in the thin-only treatment from 2002 to 2016 (Table 3; $P=0.003$ ) as ladder fuel ingrowth densified the canopy from below, but $\mathrm{CBH}$ did not change in the remaining treatments $(P \geq 0.350)$.

Immediately after treatment (i.e., in 2002), CBD in thinned treatments was $55 \%$ less than in unthinned treatments (Fig. 3; Table 2; $P<0.001$ ). In 2016, CBDs were more similar among treatments than in 2002, but still varied significantly by treatment (Table 2). Burned treatments had 33\% lower CBDs than unburned treatments $(P=0.0314)$, and thinned treatments had $46 \%$ lower CBDs than unthinned treatments $(P=0.004)$. Although change in CBD between 2002 and 2016 appears to vary by thinning (reduction in unthinned due to MPB-caused tree mortality and accumulation in thinned due to ingrowth), reduction was only significant for the burn-only treatment (Table $3 ; P=0.040$ ) and accumulation for the thin-only treatment $(P=0.008)$.

\section{Surface and crown fire potential}

The FFE-FVS software keyed at least one fire behavior fuel model to each plot, but fuel model 8 ("closed timber litter") was the most commonly assigned model across 2002 treatments (Table 4). Fuel model 8 was also the most assigned model in thinned treatments in 2016, but the unthinned treatments were better characterized by fuel model 10 ("timber [litter and understory]"), with occasional assignments of fuel model 12 ("medium logging slash"). Predicted surface fire flame length was greatest in the thin-only treatment and lowest in the burn-only treatment in 2002, but the thin-only treatment had the lowest predicted flame lengths in 2016. In 2002, crown fire (passive type) was only predicted for the burned treatments (13\% of plots). Passive crown fire was predicted for all treatment types in 2016 . However, the control had the greatest propensity by far for crown fire, whether active, passive, or conditional. 
Table 2 Nested ANOVA of fuel and crown fire potential by treatment following the Fire and Fire Surrogate Study's fuel treatments in 2002 (immediately after treatment) and in 2016 (following the 2005 to 2012 regional mountain pine beetle outbreak). NumDF

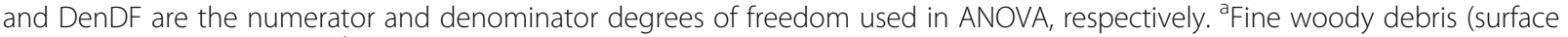
wood $<7.62 \mathrm{~cm}$ diameter); ${ }^{b}$ Coarse woody debris (sound surface wood $\geq 7.62 \mathrm{~cm}$ diameter); ${ }^{C}$ Litter and duff (litter and duff layers); ${ }^{\mathrm{d} C a n o p y ~ f u e l s ~(f o l i a g e ~ a n d ~ m a t e r i a l s ~}<7.62 \mathrm{~cm}$ diameter); ${ }^{e}$ Canopy base height (lowest height where canopy bulk density exceeds $0.011 \mathrm{~kg} \mathrm{~m}^{-3}$ ); ${ }^{\mathrm{f} C a n o p y}$ bulk density (maximum canopy fuel mass per volume given $4.5 \mathrm{~m}$ running mean); ${ }^{9}$ Probability of torching (probability of surface fire ascending into crowns given Monte Carlo simulation); ${ }^{h}$ Crowning index (6.1 m wind speed required to cause active crown fire)

\begin{tabular}{|c|c|c|c|c|c|c|c|}
\hline \multirow[t]{2}{*}{ Response } & \multirow[t]{2}{*}{ Source } & \multirow[t]{2}{*}{ NumDF } & \multirow[t]{2}{*}{ DenDF } & \multicolumn{2}{|l|}{2002} & \multicolumn{2}{|l|}{2016} \\
\hline & & & & F-statistic & $P$-value & F-statistic & $P$-value \\
\hline \multirow[t]{5}{*}{$\overline{F W D}\left(\mathrm{Mg} \mathrm{ha}^{-1}\right)$} & Intercept & 1 & 108 & 108.85 & $<0.0001$ & 714.8 & $<0.0001$ \\
\hline & Block & 2 & 6 & 5.93 & 0.0380 & 1.33 & 0.3320 \\
\hline & Burning & 1 & 6 & 24.83 & 0.0025 & 1.28 & 0.3018 \\
\hline & Thinning & 1 & 6 & 32.56 & 0.0013 & 8.38 & 0.0275 \\
\hline & Thinning $\times$ Burning & 1 & 6 & 8.94 & 0.0243 & 0.11 & 0.7527 \\
\hline \multirow[t]{5}{*}{$\mathrm{CWD}^{\mathrm{b}}\left(\mathrm{Mg} \mathrm{ha}^{-1}\right)$} & Intercept & 1 & 108 & 71.79 & $<0.0001$ & 90.25 & $<0.0001$ \\
\hline & Block & 2 & 6 & 0.80 & 0.4914 & 0.54 & 0.6077 \\
\hline & Burning & 1 & 6 & 2.95 & 0.1369 & 0.18 & 0.6890 \\
\hline & Thinning & 1 & 6 & 1.44 & 0.2758 & 26.93 & 0.0020 \\
\hline & Thinning $\times$ Burning & 1 & 6 & 1.17 & 0.3203 & 2.31 & 0.1792 \\
\hline \multirow[t]{5}{*}{$\operatorname{LD}^{\mathrm{C}}\left(\mathrm{Mg} \mathrm{ha}^{-1}\right)$} & Intercept & 1 & 108 & 306.12 & $<0.0001$ & 1916.24 & $<0.0001$ \\
\hline & Block & 2 & 6 & 0.77 & 0.5028 & 0.74 & 0.5160 \\
\hline & Burning & 1 & 6 & 39.95 & 0.0007 & 0.12 & 0.7420 \\
\hline & Thinning & 1 & 6 & 3.93 & 0.0949 & 0.20 & 0.6674 \\
\hline & Thinning $\times$ Burning & 1 & 6 & 7.00 & 0.0382 & 0.22 & 0.6538 \\
\hline \multirow[t]{5}{*}{$\mathrm{CF}^{\mathrm{d}}\left(\mathrm{Mg} \mathrm{ha}^{-1}\right)$} & Intercept & 1 & 108 & 276.03 & $<0.0001$ & 284.01 & $<0.0001$ \\
\hline & Block & 2 & 6 & 1.07 & 0.3999 & 2.04 & 0.2109 \\
\hline & Burning & 1 & 6 & 1.69 & 0.2409 & 5.33 & 0.0604 \\
\hline & Thinning & 1 & 6 & 46.79 & 0.0005 & 3.89 & 0.0959 \\
\hline & Thinning $\times$ Burning & 1 & 6 & 0.01 & 0.9356 & 1.16 & 0.3225 \\
\hline \multirow[t]{5}{*}{$\mathrm{CBH}^{\mathrm{e}}(\mathrm{m})$} & Intercept & 1 & 105 & 345.6 & $<0.0001$ & 258.37 & $<0.0001$ \\
\hline & Block & 2 & 6 & 0.99 & 0.4251 & 3.73 & 0.0884 \\
\hline & Burning & 1 & 6 & 3.03 & 0.1323 & 15.03 & 0.0082 \\
\hline & Thinning & 1 & 6 & 60.38 & 0.0002 & 15.67 & 0.0075 \\
\hline & Thinning $\times$ Burning & 1 & 6 & 1.83 & 0.2247 & 3.96 & 0.0938 \\
\hline \multirow[t]{5}{*}{$\mathrm{CBD}^{f}\left(\mathrm{~kg} \mathrm{~m}^{-3}\right)$} & Intercept & 1 & 105 & 315.84 & $<0.0001$ & 1674.82 & $<0.0001$ \\
\hline & Block & 2 & 6 & 0.44 & 0.6636 & 3.23 & 0.1118 \\
\hline & Burning & 1 & 6 & 0.82 & 0.4012 & 7.81 & 0.0314 \\
\hline & Thinning & 1 & 6 & 52.78 & 0.0003 & 20.16 & 0.0041 \\
\hline & Thinning $\times$ Burning & 1 & 6 & 0.02 & 0.9003 & 0.00 & 0.9467 \\
\hline \multirow[t]{5}{*}{$\mathrm{PT}^{\mathrm{g}}(\%)$} & Intercept & 1 & 105 & 38.18 & $<0.0001$ & 151.13 & $<0.0001$ \\
\hline & Block & 2 & 6 & 0.13 & 0.8768 & 4.32 & 0.0688 \\
\hline & Burning & 1 & 6 & 22.85 & 0.0031 & 0.85 & 0.3920 \\
\hline & Thinning & 1 & 6 & 15.81 & 0.0073 & 18.73 & 0.0049 \\
\hline & Thinning $\times$ Burning & 1 & 6 & 0.57 & 0.4775 & 0.40 & 0.5510 \\
\hline
\end{tabular}


Table 2 Nested ANOVA of fuel and crown fire potential by treatment following the Fire and Fire Surrogate Study's fuel treatments in 2002 (immediately after treatment) and in 2016 (following the 2005 to 2012 regional mountain pine beetle outbreak). NumDF and DenDF are the numerator and denominator degrees of freedom used in ANOVA, respectively. ${ }^{\mathrm{a}}$ Fine woody debris (surface

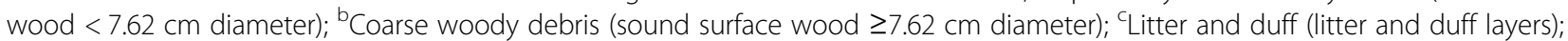
${ }^{\mathrm{d} C a n o p y ~ f u e l s ~(f o l i a g e ~ a n d ~ m a t e r i a l s ~}<7.62 \mathrm{~cm}$ diameter); ${ }^{e}$ Canopy base height (lowest height where canopy bulk density exceeds $\left.0.011 \mathrm{~kg} \mathrm{~m}^{-3}\right) ;{ }^{f}$ Canopy bulk density (maximum canopy fuel mass per volume given $4.5 \mathrm{~m}$ running mean); ${ }^{9}$ Probability of torching (probability of surface fire ascending into crowns given Monte Carlo simulation); ${ }^{h}$ Crowning index (6.1 m wind speed required to cause active crown fire) (Continued)

\begin{tabular}{|c|c|c|c|c|c|c|c|}
\hline \multirow[t]{2}{*}{ Response } & \multirow[t]{2}{*}{ Source } & \multirow[t]{2}{*}{ NumDF } & \multirow[t]{2}{*}{ DenDF } & \multicolumn{2}{|l|}{2002} & \multicolumn{2}{|l|}{2016} \\
\hline & & & & F-statistic & $P$-value & F-statistic & $P$-value \\
\hline \multirow[t]{5}{*}{$\mathrm{Cl}^{\mathrm{h}}\left(\mathrm{km} \mathrm{h}^{-1}\right)$} & Intercept & 1 & 105 & 704.41 & $<0.0001$ & 306.23 & $<0.0001$ \\
\hline & Block & 2 & 6 & 2.45 & 0.167 & 1.49 & 0.299 \\
\hline & Burning & 1 & 6 & 1.80 & 0.2288 & 7.14 & 0.0369 \\
\hline & Thinning & 1 & 6 & 54.16 & 0.0003 & 8.79 & 0.0251 \\
\hline & Thinning $\times$ Burning & 1 & 6 & 0.01 & 0.9294 & 1.44 & 0.2754 \\
\hline
\end{tabular}

PT in 2002 depended on both burning and thinning treatments (Fig. 4; Table 2). Burning reduced PT by $64 \%$ $(P=0.003)$ and thinning reduced it by $34 \%(P=0.007)$. Probability of torching in 2016 was only dependent on thinning (Table 3). In this case, unthinned treatment PT was $111 \%$ greater than thinned treatments probabilities $(P=0.005)$. Between 2002 and 2016, PT in unthinned treatments significantly increased with inputs to the surface fuel loading (Table $3 ; P \leq 0.036$ ), but PT did not significantly change in thinned treatments $(P \geq 0.124)$.

CI differed by thinning in 2002 (Fig. 4; Table 2), which was expected because thinning reduced CBDs. More specifically, thinning resulted in $95 \%$ greater CIs than the unthinned treatments. By 2016, CI differed by both burning and thinning (Table 2). Burned units had 37\% greater CI than unburned units $(P=0.037)$ and thinned units had $42 \%$ greater $C I$ than unthinned units $(P=0.025)$. Although the ANOVA interaction term was not significant, pairwise differences revealed that the thin +burn treatment had $48 \%$ to $89 \%$ greater CI than the remaining treatments. CIs remained relatively constant between 2002 and 2016 except for in the thin-only treatment, where it dropped significantly as ingrowth densified the canopy (Table $3 ; P=0.019$ ).

\section{Fuel and crown fire potential mediation}

Differences in fuel loading between control and thinning treatments were mediated by the MPB outbreak, but the outbreak did not affect differences in loading between the control and burn-only treatments (Fig. 5). The significantly non-zero indirect effects in the thin-only and thin+burn for FWD, CWD, and CF responses demonstrate that the MPB outbreak mediated differences between control and thinned treatments for three of our four fuel loading metrics. Substantial (standardized effect size $P>0.05$ ) indirect effects were consistent with total effect direction for all responses except for CF, meaning that the MPB outbreak generally increased contrasts between control and treatments, but decreased CF differences between control and thinned treatments.

Consistent with fuel loadings, differences in $\mathrm{CBH}$, $\mathrm{CBD}$, and crown fire potential metrics between control and thinning treatments depended on the MPB outbreak, but differences between control and burn-only did not (Fig. 5). Thin-only indirect effects were significantly non-zero for $\mathrm{CBD}, \mathrm{PT}$, and $\mathrm{CI}$, while thin+burn indirect effects were only significant for $\mathrm{CBD}$ and $\mathrm{PT}$. Thus, the MPB outbreak did not affect CBH differences between control and treatments, nor did it affect any response differences between control and burn-only. Indirect effects were consistent with total effect directions only for PT; they were inconsistent with total effects for $\mathrm{CBH}, \mathrm{CBD}$, and $\mathrm{CI}$. The magnitude and direction of indirect effects on PT illustrate that most of the difference between the control and thinned treatments was due to the MPB outbreak. Conversely, the MPB outbreak obscured differences in $\mathrm{CBH}, \mathrm{CBD}$, and $\mathrm{CI}$ between control and thinned treatments.

\section{Discussion}

This study characterized fuel development and crown fire potential dynamics 14 years after initial treatment and at least 4 years following an MPB outbreak. In general, we observed that fuel loading was elevated after the outbreak and ingrowth, and potential for crown fire was greatest in the untreated control, intermediate in burn-only and thin-only, and lowest in thin+burn (Table 5).

Despite the subsequent biotic disturbance, the primary management objective in these treated units is still to resist crown fire. Interaction between disturbances such as a beetle outbreak and fire has been a growing concern (Bebi et al. 2003, Schoennagel et al. 2012, Jenkins et al. 2014, 
Table 3 Fuel and crown fire potential change by treatment between 2002 (immediately following treatment) and 2016 (following the 2005 to 2012 regional mountain pine beetle outbreak) at the Fire and Fire Surrogate Study. Estimates were derived and tested against zero using linear mixed effects models. ${ }^{a}$ Fine woody debris (surface wood $<7.62 \mathrm{~cm}$ diameter); ${ }^{b}$ Coarse woody debris (sound surface wood $\geq 7.62 \mathrm{~cm}$ diameter); ${ }^{C}$ Litter and duff (litter and duff layers); ${ }^{\mathrm{d} C a n o p y}$ fuels (foliage and materials $<7.62 \mathrm{~cm}$ diameter); ${ }^{~}$ Canopy base height (lowest height where canopy bulk density exceeds $0.011 \mathrm{~kg} \mathrm{~m}^{-3}$ ); ${ }^{\mathrm{f}}$ Canopy bulk density (maximum canopy fuel mass per volume given $4.5 \mathrm{~m}$ running mean); ${ }^{9}$ Probability of torching (probability of surface fire ascending into crowns given Monte Carlo simulation); ${ }^{\text {h}}$ Crowning index (6.1 m windspeed required to cause active crown fire)

\begin{tabular}{|c|c|c|c|c|}
\hline Response & Treatment & Estimate & Standard error & $P$-value \\
\hline \multirow[t]{4}{*}{$\mathrm{FWD}^{\mathrm{a}}\left(\mathrm{Mg} \mathrm{ha}^{-1}\right)$} & Control & 5.17 & 1.30 & 0.0073 \\
\hline & Burn-only & 7.32 & 1.35 & 0.0016 \\
\hline & Thin-only & -11.39 & 3.04 & 0.0095 \\
\hline & Thin+Burn & -1.02 & 1.39 & 0.4904 \\
\hline \multirow[t]{4}{*}{$\mathrm{CWD}^{\mathrm{b}}\left(\mathrm{Mg} \mathrm{ha}^{-1}\right)$} & Control & 16.96 & 7.20 & 0.0565 \\
\hline & Burn-only & 12.02 & 2.99 & 0.0070 \\
\hline & Thin-only & -4.34 & 1.29 & 0.0152 \\
\hline & Thin+Burn & -0.71 & 1.29 & 0.6007 \\
\hline \multirow[t]{4}{*}{$\operatorname{LD}^{c}\left(\mathrm{Mg} \mathrm{ha}^{-1}\right)$} & Control & -8.59 & 4.14 & 0.0832 \\
\hline & Burn-only & 13.14 & 2.28 & 0.0012 \\
\hline & Thin-only & -0.25 & 2.66 & 0.9288 \\
\hline & Thin+Burn & 9.82 & 2.32 & 0.0055 \\
\hline \multirow[t]{4}{*}{$\mathrm{CF}^{\mathrm{d}}\left(\mathrm{Mg} \mathrm{ha}^{-1}\right)$} & Control & -7.61 & 3.09 & 0.0488 \\
\hline & Burn-only & -7.06 & 2.02 & 0.0128 \\
\hline & Thin-only & 9.47 & 0.76 & $<0.0001$ \\
\hline & Thin+Burn & 3.58 & 1.11 & 0.0177 \\
\hline \multirow[t]{4}{*}{$\mathrm{CBH}^{\mathrm{e}}(\mathrm{m})$} & Control & -0.34 & 0.53 & 0.5479 \\
\hline & Burn-only & 0.53 & 0.52 & 0.3498 \\
\hline & Thin-only & -2.54 & 0.52 & 0.0028 \\
\hline & Thin+Burn & -0.31 & 0.55 & 0.5941 \\
\hline \multirow[t]{4}{*}{$\operatorname{CBD}^{f}\left(\mathrm{~kg} \mathrm{~m}^{-3}\right)$} & Control & -0.006 & 0.007 & 0.4431 \\
\hline & Burn-only & -0.017 & 0.007 & 0.0404 \\
\hline & Thin-only & 0.015 & 0.004 & 0.0080 \\
\hline & Thin+Burn & 0.005 & 0.004 & 0.2406 \\
\hline \multirow[t]{4}{*}{$\mathrm{PT}^{\mathrm{g}}(\%)$} & Control & 20.46 & 7.61 & 0.0361 \\
\hline & Burn-only & 32.97 & 7.50 & 0.0046 \\
\hline & Thin-only & 4.22 & 7.50 & 0.5938 \\
\hline & Thin+Burn & 14.02 & 7.83 & 0.1237 \\
\hline \multirow[t]{4}{*}{$\mathrm{Cl}^{\mathrm{h}}\left(\mathrm{km} \mathrm{h}^{-1}\right)$} & Control & 5.84 & 8.33 & 0.5096 \\
\hline & Burn-only & 11.41 & 8.19 & 0.2130 \\
\hline & Thin-only & -25.95 & 8.19 & 0.0193 \\
\hline & Thin+Burn & 0.77 & 8.63 & 0.9318 \\
\hline
\end{tabular}

Kane et al. 2017), but other studies have not specifically considered this interaction within treated areas. To more satisfactorily address the drivers and outcomes of combined treatment and MPB-caused tree mortality effects, we discuss the mediation analysis prior to the assessment of fuel and crown fire potential dynamics.

\section{Are differences driven by silvicultural treatment or MPB?}

To effectively interpret treatment outcomes we must begin with the relationship between the two "treatment" components in 2016: silvicultural fuel reduction and MPB-caused tree mortality. Studies have shown endemic (non-outbreak) beetle populations can cause additional mortality in response to burning treatments, killing injured or less vigorous trees that may have survived burning alone (e.g., Larsson et al. 1983, Negrón and Popp 2004, Fettig et al. 2010). On our sites, Six and Skov (2009) identified that, by 2008, three bark beetle species (Douglas-fir beetle [Dendroctonus pseudotsugae Hopkins], pine engraver [Ips pini Say], and western pine beetle [Dendroctonus brevicomis LeConte]) increased in abundance because of burning treatments. MPB population size did not respond to treatment, but successful MPB attacks were more prevalent in unthinned treatments. By 2012, the regional MPB outbreak had caused high overstory mortality in the control (50\%) and burn-only (39\%) treatment units, leading to similar live ponderosa pine basal areas across all treatments (Hood et al. 2016).

We applied these MPB-caused tree mortality data to our mediation analysis, confirming that fuel treatment and MPB-caused mortality were inextricably linked: the number of overstory trees killed had a strong negative association with thinning and a slight positive association with burning. In addition to characterizing the combined effects of these "treatments," our analysis ascertains the relative effects of silviculture and MPB on forest fuels and crown fire potential, including treatment-outbreak agreement or antagonism (Fig. 5; Table 5).

A number of studies have shown that, in unmanaged units, MPB-caused mortality alters forest fuel profiles (summarized in Jenkins et al. 2012, but see Simard et al. 2011). Our mediation analysis illustrates that CF loading after the outbreak was significantly lower in thin+burn than control despite high MPB-caused tree mortality in control units, and FWD loading was lower in thin+burn units because of the high MPB-caused tree mortality. Additionally, MPB-caused tree mortality inflated differences between thinned and control units in FWD and CWD pools, but reduced existing differences in the CF pool. These linked fuel loadings demonstrate that $\mathrm{MPB}$ caused fuel transfer from overstory to surface pools, and that although MPB-caused tree mortality partially masked or diminished differences between thinned and unthinned 


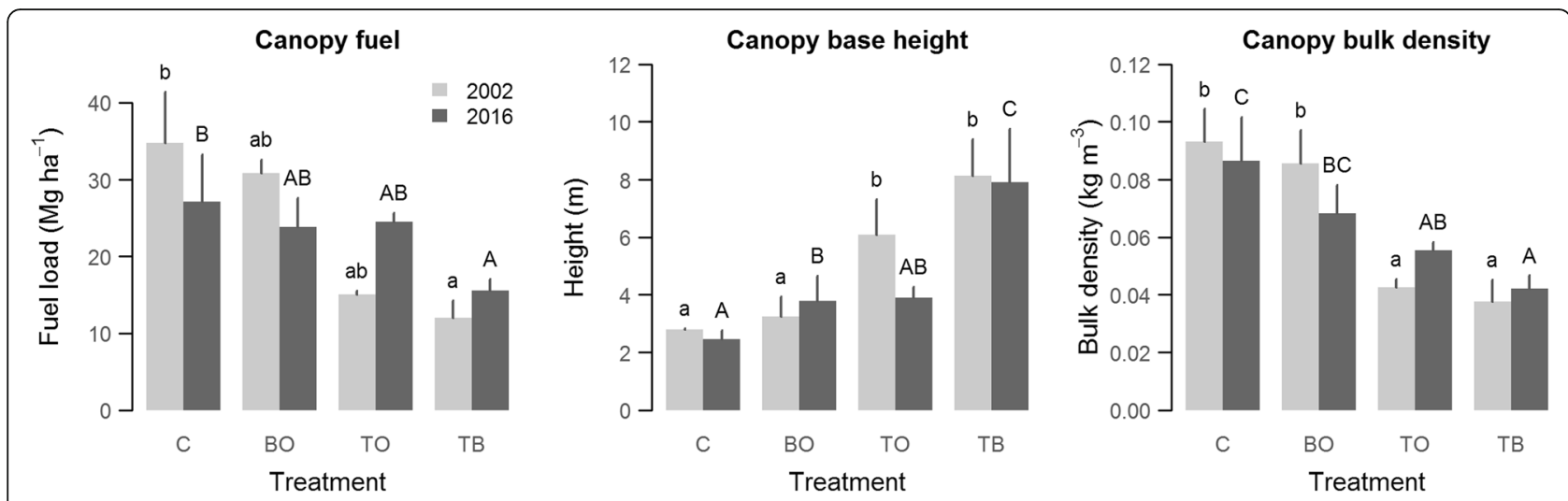

Fig. 3 Canopy fuel characteristics (mean and standard error) by treatment following the northern Rocky Mountains' Fire and Fire Surrogate Study's fuel treatments in 2002 (immediately after treatment) and in 2016 (following the 2005 to 2012 regional mountain pine beetle outbreak). $\mathrm{C}=$ Control, $\mathrm{BO}=$ Burn-only, $\mathrm{TO}=$ Thin-only, $\mathrm{TB}=$ Thin+Burn. Canopy fuel loading include foliage and materials $<7.62 \mathrm{~cm}$ diameter; canopy base height is the lowest height at which canopy bulk density exceeds $0.011 \mathrm{~kg} \mathrm{~m}^{-3}$; canopy bulk density is the maximum canopy fuel mass per volume given $4.5 \mathrm{~m}$ running mean. Letters above bars denote pairwise differences between treatments (lowercase $=2002$ differences, uppercase = 2016 differences); letters are not shown when ANOVA tests were not significant.

canopies, unthinned canopy fuels translocated to the ground inflated surface fuel loading beyond thinned treatments. The nature of these differences is also manifested in the divergence of assigned fire behavior fuel models by treatments. FFE-FVS assigned slash group fire behavior fuel models ("medium logging slash" and "heavy logging slash") to characterize unthinned surface fuel profiles, which is expected to make potential fire behavior more volatile, increasing soil heating and belowground severity.

Although MPB-caused tree mortality inflated surface fuel differences between thinned and control units, our analysis of fire potential indicated MPB only inflated differences in PT between those treatments. Studies have shown that an MPB outbreak can exacerbate fire behavior, depending on time since disturbance and metrics analyzed (synthesized in Jenkins et al. 2014, but see Harvey et al. 2013). But beyond beetle-caused inputs to surface fuels, beetles actually thin out forest canopies and eventually moderate potential crown fire spread, akin to the silviculturist's fuel treatments. Our analysis shows that MPB-caused tree mortality-which was greater in unthinned units-offsets the initial positive effect of thinning on canopy fuel (CBD) and therefore crown fire potential (CI). However, since this offset effect is minor (indirect effect magnitude was smaller than direct effect magnitude), it demonstrates that "natural thinning" by MPB neither reduces crown fire potential as well as active management nor hinders the effective longevity of silvicultural thinning. PT, on the other hand, incorporates

Table 4 Dominant fuel models and potential fire behavior by treatment following the Fire and Fire Surrogate Study's fuel treatments in 2002 (immediately after treatment) and in 2016 (following the 2005 to 2012 regional mountain pine beetle outbreak). Fuel models and fire behavior were determined using the Fire and Fuels Extension of the Forest Vegetation Simulator (FFE-FVS) Predicted fire behavior is based on standard severe fire weather conditions (FFE-FVS "severe" category: $4 \%$ 10-h fuel moisture, $21.1^{\circ} \mathrm{C}_{\text {, and } 32.2 \mathrm{~km} \mathrm{~h}}{ }^{-1} 6.1 \mathrm{~m} \mathrm{wind}$ speed. Fuel model numbers refer to those developed by Albini (1976). Predicted fire type refers to categories outlined by Scott and Reinhardt (2001)

\begin{tabular}{|c|c|c|c|c|c|c|c|c|c|c|}
\hline \multirow[t]{3}{*}{ Year } & \multirow[t]{3}{*}{ Treatment } & \multicolumn{4}{|c|}{ Primary fuel model } & \multirow{3}{*}{$\begin{array}{l}\text { Surface } \\
\text { flame } \\
\text { length } \\
\text { (m) }\end{array}$} & \multicolumn{4}{|c|}{ Predicted fire type } \\
\hline & & 8 & 10 & 12 & \multirow[t]{2}{*}{13} & & Surface & Conditional & Passive & \multirow[t]{2}{*}{ Active } \\
\hline & & \multicolumn{3}{|c|}{ Percent occurence } & & & \multicolumn{3}{|c|}{ Percent occurence } & \\
\hline 2002 & Control & $67(3)$ & $27(7)$ & $7(3)$ & $0(0)$ & $0.83(0.01)$ & $63(13)$ & $23(12)$ & $13(3)$ & $0(0)$ \\
\hline 2002 & Burn-only & $93(3)$ & $7(3)$ & $0(0)$ & $0(0)$ & $0.43(0.06)$ & $80(10)$ & $20(10)$ & $0(0)$ & $0(0)$ \\
\hline 2002 & Thin-only & $53(3)$ & $30(0)$ & $17(3)$ & $0(0)$ & $1.54(0.03)$ & $87(3)$ & $0(0)$ & $13(3)$ & $0(0)$ \\
\hline 2002 & Thin+Burn & $93(3)$ & $3(3)$ & $3(3)$ & $0(0)$ & $0.71(0.13)$ & $100(0)$ & $0(0)$ & $0(0)$ & $0(0)$ \\
\hline 2016 & Control & $33(20)$ & $40(15)$ & $23(19)$ & $3(3)$ & $1.56(0.32)$ & $40(15)$ & $17(12)$ & $40(15)$ & $3(3)$ \\
\hline 2016 & Burn-only & $37(9)$ & $50(10)$ & $13(3)$ & $0(0)$ & $1.50(0.13)$ & $70(12)$ & $7(7)$ & $23(7)$ & $0(0)$ \\
\hline 2016 & Thin-only & $70(6)$ & $30(6)$ & $0(0)$ & $0(0)$ & $1.11(0.03)$ & $83(3)$ & $0(0)$ & $17(3)$ & $0(0)$ \\
\hline 2016 & Thin+Burn & $60(0)$ & $40(0)$ & $0(0)$ & $0(0)$ & $1.47(0.11)$ & $90(6)$ & $0(0)$ & $10(6)$ & $0(0)$ \\
\hline
\end{tabular}




\section{Probability of torching}
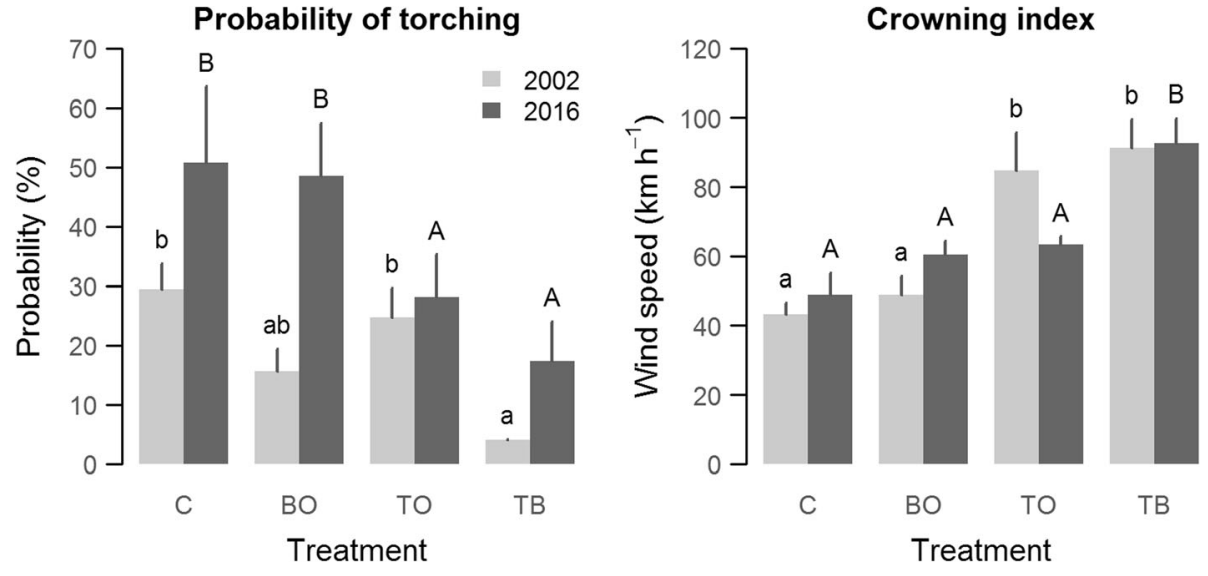

Fig. 4 Crown fire potential (mean and standard error) by treatment following the northern Rocky Mountains' Fire and Fire Surrogate Study's fuel treatments (completed in 2001) and regional mountain pine beetle outbreak (2005 to 2012). $C=$ Control, $B O=B$ urn-only, $T O=T h i n-o n l y, ~ T B=$ Thin+Burn. Probability of torching is the probability of surface fire ascending into crowns given Monte Carlo simulation; crowning index is the $6.1 \mathrm{~m}$ wind speed required to cause active crown fire. Letters above bars denote pairwise differences between treatments (lowercase $=2002$ differences, uppercase $=2016$ differences); letters are not shown when ANOVA tests were not significant.

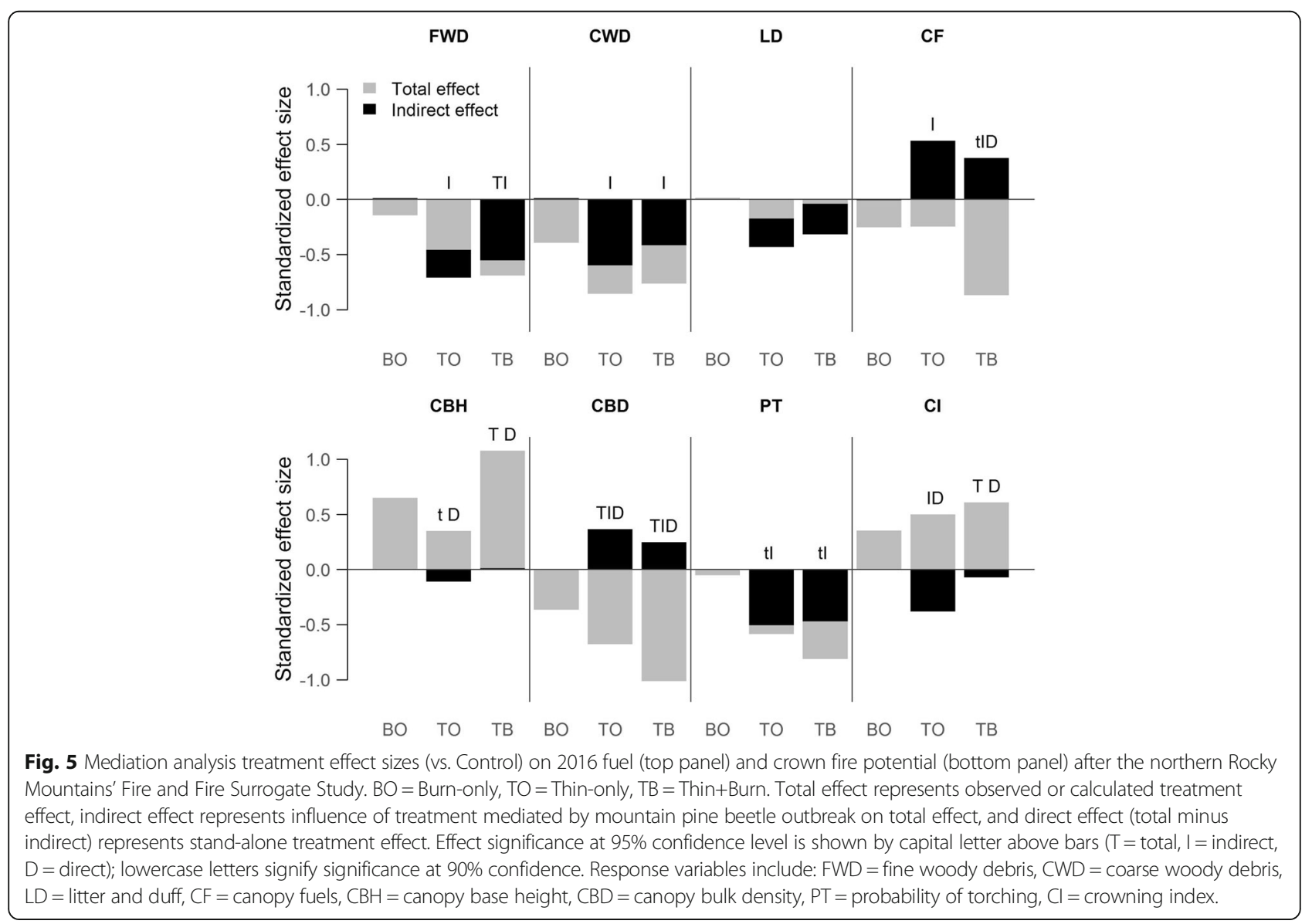


Table 5 Summary of fuel load and crown fire potential differences by treatment at the Fire and Fire Surrogate Study. Fuel and crown fire potential attributes: FWD = fine woody debris load, CWD = coarse woody debris loading, $\mathrm{LD}=$ litter and duff loading, $\mathrm{CF}=$ canopy fuel loading, $\mathrm{CBH}=$ canopy base height, $\mathrm{CBD}=$ canopy bulk density, $\mathrm{PT}=$ probability of torching, $\mathrm{Cl}=$ crowing index

\begin{tabular}{|c|c|c|c|c|c|c|c|c|}
\hline \multirow[t]{2}{*}{ Treatment } & \multicolumn{8}{|c|}{2002 to 2016 change $^{a}$} \\
\hline & FWD & CWD & LD & CF & $\mathrm{CBH}$ & CBD & PT & $\mathrm{Cl}$ \\
\hline Control & $\uparrow$ & $\uparrow$ & $\downarrow$ & $\downarrow$ & & & $\uparrow$ & \\
\hline Burn-only & $\uparrow$ & $\uparrow$ & $\uparrow$ & $\downarrow$ & & $\downarrow$ & $\uparrow$ & \\
\hline Thin-only & $\downarrow$ & & $\downarrow$ & $\uparrow$ & $\downarrow$ & $\uparrow$ & & $\downarrow$ \\
\hline \multirow[t]{3}{*}{ Thin+Burn } & & & $\uparrow$ & $\uparrow$ & & & & \\
\hline & \multicolumn{8}{|c|}{ Beetle outbreak impact (vs. Control) ${ }^{b}$} \\
\hline & FWD & CWD & LD & CF & $\mathrm{CBH}$ & CBD & PT & $\mathrm{Cl}$ \\
\hline \multicolumn{9}{|l|}{ Control } \\
\hline \multicolumn{9}{|l|}{ Burn-only } \\
\hline Thin-only & $\longleftrightarrow$ & $\longleftrightarrow$ & & $\rightarrow \leftarrow$ & & $\rightarrow \leftarrow$ & $\hookleftarrow$ & $\rightarrow \leftarrow$ \\
\hline \multirow[t]{3}{*}{ Thin+Burn } & $\longleftrightarrow$ & $\longleftrightarrow$ & & $\rightarrow \leftarrow$ & & $\rightarrow \leftarrow$ & $\longleftrightarrow$ & \\
\hline & \multicolumn{8}{|c|}{2016 Tukey-Kramer rank ${ }^{c}$} \\
\hline & FWD & CWD & LD & CF & $\mathrm{CBH}$ & CBD & PT & $\mathrm{Cl}$ \\
\hline Control & B & B & & B & A & $C$ & B & $A$ \\
\hline Burn-only & $A B$ & B & & $A B$ & B & $B C$ & B & A \\
\hline Thin-only & $A B$ & A & & $A B$ & $A B$ & $A B$ & $A B$ & A \\
\hline Thin+Burn & A & A & & A & C & A & A & B \\
\hline
\end{tabular}

${ }^{a}$ Statistically significant differences $(a=0.10)$ between 2002 and 2016 values. $\uparrow$ $=$ values increased, $\downarrow=$ values decreased, blank $=$ no change

${ }^{b}$ Statistically significant effect $(a=0.10)$ of beetle outbreak on treatment effect over control. $\leftarrow \rightarrow=$ treatment and control differences inflated, $\rightarrow \leftarrow=$ treatment and Control differences diminished, blank $=$ no effect 'Statistically significant pairwise differences $(\alpha=0.05)$ at 2016 measurement. Shared letters indicate no difference. $\mathrm{A}=$ lowest value, blank = no difference

potential surface fire behavior where the canopy-based metrics do not. Silviculture and MPB effects had consistent influence on the thinning versus control contrast for this metric because silvicultural thinning reduces PT but MPB-caused tree mortality increases it by compounding ladder fuels with heavy surface loading, inflating the difference (in fuel loading and longevity) between thinned and unthinned units.

We found no fuel or crown fire potential differences (treatment or MPB caused) between burn-only and control treatments. This is likely because the prescribed burning treatment was mostly kept to low fire intensities to limit overstory mortality. Fire effects were also limited because many trees, including successional species, had grown to fire-tolerant sizes in the fire-excluded twentieth century. The burning effect may have been muddled by MPB if the treatment was more severe and had more strongly influenced successful beetle attacks (Wallin et al. 2003) or reduced overstory density as much as thinning treatments. When combined with thinning in the form of the thin+burn treatment, however, we did observe a minor effect of MPB on burned treatments: MPB effects in the thin+burn treatments were always slightly less than in the thin-only treatment, even to the point of being absent in the CI contrast. This is because treatment more poorly differentiated MPB-caused tree mortality between thin+burn and control than between thin-only and control (leg $a$ of Fig. 1). Thus, the MPB outbreak obfuscated the thin-only versus control contrast on crown fire spread (CI), but did not impact the thin+burn contrast, suggesting that differences were mostly due to prescribed burning treatment.

\section{Combined effects: the state of treatment in 2016}

Disentangling the silviculture and MPB effects on fuel treatments in 2016 is useful for understanding the relative importance of these factors on the fuel development process and on change in crown fire potential, but land managers may be more concerned with the resultant state of treatment fuel loading and crown fire potential. In this sense, treatment effectiveness at maintaining low crown fire potential may be a more practically important matter than effect mediation.

We found that thinned units had less fuel and lower crown fire potential than unthinned units in 2016. One major difference between 2002 and 2016 thinning effects was the radical increase of surface fuel (FWD and CWD) in unthinned units, which likely would not have happened without the MPB outbreak. These surface fuels are directly tied to increased surface fire behavior and potential for torching. Although thinning was a statistically significant predictor of PT in both 2002 and 2016, 2016 probabilities were higher in unthinned (50\%) than thinned units and therefore more significant, and undesirable, in practical terms. This condition is typical of unmanaged second-growth ponderosa pine -Douglas fir forests impacted by beetles throughout the Interior West and reflects that torching and crowning fire behavior may be commonplace in many unmaintained, post-outbreak units (Jain et al. 2012).

We also found that burned units had less canopy fuel and lower probabilities of sustaining crown fire than unburned units in 2016. Interestingly, we observed delayed effects of burning on canopy fuel characteristics and crown fire potential $(\mathrm{CBH}, \mathrm{CBD}, \mathrm{CI})$ that were not present in 2002. This delay is likely due to secondary fire-induced mortality, namely pre-MPB-outbreak attacks by other beetles on trees weakened by prescribed fire, as documented by Six and Skov (2009). Despite these two beetle episodes (endemic then epidemic) in the burn-only treatment, and that the control was only slightly different from the burn-only in all of the 2016 fuel and crown fire potential facets, FFE-FVS predicted "surface" type fire only $40 \%$ of the time in the control versus $70 \%$ in the burn-only. Fire (and fire modeling) is very sensitive to thresholds in fuels, weather, and topography. Although the 
potential fire behavior metrics that this study presents are more valuable for comparative analysis than absolute characterization, they illustrate that prescribed fire may only have mild effects on measured vegetation and fuels structure, but still reduce potential fire behavior below important crowning thresholds.

The combination of thinning and burning is clearly the most effective at sustaining low crown fire potential in light of post-treatment growth and subsequent disturbance. The 2016 thin+burn was superior to the burn-only and thin-only treatments for three main reasons. First, it reduced surface and canopy fuels. Combined thinning and burning most effectively reduces fuels because thinning removes substantial tree and canopy biomass, while burning consumes surface fuels that have built up prior to thinning in addition to activity fuels (Stephens and Moghaddas 2005). Second, thin+burn reduced MPB-caused mortality relative to control and burn-only. Although thinning during outbreak-level disturbances may be ineffective (Six et al. 2014), thinning prior to an outbreak has been shown to moderate mortality (Fettig et al. 2014, Jenkins et al. 2014, Hood et al. 2016). Third, the thin+burn dampened development of ladder fuels by killing regeneration and potential ingrowth present after commercial thinning. Keyes and O'Hara (2002) identified that fuel treatments stimulate forest regeneration, and in turn negate fuel reduction objectives. Although thin+burn units are in fact regenerating, the combination of these treatments killed advanced regeneration and reset an understory development phase, lengthening the duration of treatment effectiveness. The recent divergence from thin-only emphasizes that treating the understory is imperative for extending the duration of treatment longevity. Although stand densities in both thin-only and thin +burn were most similar to stand densities in local historical units with intact frequent fire regimes (e.g., per Clyatt et al. 2016), without re-entry or burning, the thin-only treatment may not be able to resist crown fire like the thin+burn or historical, open ponderosa pine units (Arno et al. 2008). Although the thin+burn treatment had slightly greater MPB-caused mortality than thin-only, fuel treatments in ponderosa pine forest types that include both thinning and burning (i.e., because burning treated the understory) best establish forest structure that is able to resist both beetles and crown fire well into the second decade. This timeframe is especially important for ponderosa pine forests in the inland Northwest, where fire return intervals may range up to half a century (Arno et al. 1995) and managers may be financially or logistically unable to keep up fuel treatments.

\section{Conclusion}

Fuel treatments have been widely implemented to reduce crown fire potential in fire-prone forests. However, recent bark beetle outbreaks have impacted millions of hectares of unmanaged and managed forests throughout the West. This study shows that fuel treatments followed by an MPB outbreak generate their own unique responses that differ from original treatment responses. Overall, thinned then MPBattacked units had less fuel and lower crown fire potential than unthinned attacked units. Burned then beetle-attacked units had less canopy fuel and also had lower crown fire potential than unburned attacked units. Combined thinning and burning best improved fuel treatment longevity; even after MPB outbreak, this treatment exhibited little change in fuel profile and crown fire potential.

Bark beetle outbreaks reduce live stem densities and canopy fuels. However, bark beetle outbreaks and fuel treatments typically target different tree sizes and species, resulting in different forest structures and species composition, and these differences can have profound impacts on potential fire behavior. The MPB outbreak in our study had a complex effect on fuels and crown fire potential in treated versus untreated units, amplifying some differences and reducing others. High levels of MPB-caused mortality in control units and ladder fuel ingrowth in thin-only units made fuel and crown fire potential in these two treatments more similar in a number of ways. Despite becoming more similar to thinned treatments following MPB outbreak, control treatments were still characterized by greater crown fire potential, emphasizing a key difference between silvicultural and MPB "treatment."

\section{Acknowledgements \\ This was a study of the Applied Forest Management Program at the University of Montana, a research and demonstration unit of the Montana Forest and Conservation Experiment Station. We are also indebted to A. Larson for providing feedback on an earlier draft.}

\section{Funding}

This work was supported by the USDA National Institute of Food and Agriculture, McIntire Stennis project 233356 (awarded to C. Keyes). The study was made possible with the foresight of past scientists who designed and implemented the Fire and Fire Surrogate Study, a nation-wide project funded by the Joint Fire Sciences Program (FFS 99-S-01).

Availability of data and materials

Data available upon request.

\section{Authors' contributions}

JSC and CRK designed the study and acquired the data. JSC performed the analysis and wrote the manuscript. JSC, CRK, SMH, DLRA, and AS contributed to data interpretation and manuscript revision. All authors read and approved the final manuscript.

Ethics approval and consent to participate

Not applicable.

Consent for publication

Not applicable.

Competing interests

The authors declare that they have no competing interests. 


\section{Publisher's Note}

Springer Nature remains neutral with regard to jurisdictional claims in published maps and institutional affiliations.

\section{Author details \\ ${ }^{1}$ University of Montana, WA Franke College of Forestry and Conservation, 32 Campus Drive, Missoula, Montana 59812, USA. ${ }^{2}$ Present address: USDA Forest Service, Pacific Northwest Research Station, 11175 Auke Lake Way, Juneau, Alaska 99801, USA. ${ }^{3}$ USDA Forest Service, Rocky Mountain Research Station, Fire, Fuel, and Smoke Science Program, 5775 Highway 10 W, Missoula, Montana 59808, USA. ${ }^{4}$ University of Montana, Division of Biological Sciences, 32 Campus Drive, Missoula, Montana 59812, USA \\ Received: 20 September 2018 Accepted: 24 September 2018 Published online: 27 December 2018}

\section{References}

Affleck, D., C. Keyes, and J. Goodburn. 2012. Conifer crown fuel modeling: Current limits and potential for improvement. Western Journal of Applied Forestry 27 (4): 165-169 https://doi.org/10.5849/wjaf.11-039.

Agee, J.K., and C.N. Skinner. 2005. Basic principles of forest fuel reduction treatments. Forest Ecology and Management 211 (1): 83-96 https://doi.org/10. 1016/j.foreco.2005.01.034.

Albini, F.A. 1976. Estimating wildfire behavior and effects. In USDA Forest Service general technical report INT-30. Intermountain Forest and Range Experiment Station, Odgen, Utah: USA.

Arno, S.F., C.E. Fiedler, and M.K. Arno. 2008. Giant pines and grassy glades. The historic ponderosa pine ecosystem, disappearing icon of the American west, Forest history today (spring), 12-19.

Arno, S.F., J.H. Scott, and G. Hartwell. 1995. Age-class structure of old growth ponderosa pine/ Douglas-fir stands and its relationship to fire history. In USDA Forest Service research paper INT-RP-481. Intermountain Research Station, Ogden, Utah: USA.

Baron, R., and D. Kenny. 1986. The moderator-mediator variable distinction in social psychological research. Journal of Personality and Social Psychology 51 (6): 1173-1182 https://doi.org/10.1037/0022-3514.51.6.1173.

Bebi, P., D. Kulakowski, and T.T. Veblen. 2003. Interactions between fire and spruce beetles in a subalpine Rocky Mountain forest landscape. Ecology 84 (2): 362-371 https://doi.org/10.1890/0012-9658(2003)084[0362:IBFASB]2.0.CO;2.

Bentz, B.J., J. Regniere, C.J. Fettig, M. Hansen, J.L. Hayes, J.A. Hicke, R.G. Kelsey, J.F. Negrón, and S. Seybold. 2010. Climate change and bark beetles of the western United States and Canada: Direct and indirect effects. BioScience 60 (8): 602-613 https://doi.org/10.1525/bio.2010.60.8.6.

Bigler, C., D. Kulakowski, and T.T. Veblen. 2005. Multiple disturbance interactions and drought influence fire severity in Rocky Mountain subalpine forests. Ecology 86 (11): 3018-3029 https://doi.org/10.1890/05-0011.

British Colombia Ministry of Forests. 2004. Bark beetle management guidebook. Britis Columbia Ministry of Forests. British Columbia, Canada: Victoria.

Brown, J.K. 1974. Handbook for inventorying downed woody material. In USDA Forest Service general technical report INT-GTR-16. Intermountain Research Station, Ogden, Utah: USA

Brown, R.T., J.K. Agee, and J.F. Franklin. 2004. Forest restoration and fire: Principles in the context of place. Conservation Biology 18 (4): 903-912 https://doi.org/ 10.1111/j.1523-1739.2004.521_1.X

Clyatt, K.A., J.S. Crotteau, M.S. Schaedel, H.L. Wiggins, H. Kelley, D.J. Churchill, and A.J. Larson. 2016. Historical spatial patterns and contemporary tree mortality in dry mixed-conifer forests. Forest Ecology and Management 361: 23-37 https://doi.org/10.1016/j.foreco.2015.10.049.

R Core Team. 2016. R: A language and environment for statistical computing. $<$ http://www.r-project.org/>. Accessed 9 Oct 2018.

Covington, W.W., and M.M. Moore. 1994. Postsettlement changes in natural fire regimes and forest structure. Journal of Sustainable Forestry 2 (1): 153-181 https://doi.org/10.1300/J091v02n01_07.

Cruz, M.G., and M.E. Alexander. 2010. Assessing crown fire potential in coniferous forests of western North America: A critique of current approaches and recent simulation studies. International Journal of Wildland Fire 19: 377-398 https://doi.org/10.1071/WF08132.

Cruz, M.G., M.E. Alexander, and R.H. Wakimoto. 2005. Development and testing of models for predicting crown fire rate of spread in conifer forest stands. Canadian Journal of Forest Research 35 (7): 1626-1639 https://doi.org/10. 1139/x05-085.
Dixon, G. 2002. Essential FVS: A user's guide to the Forest vegetation simulator. USDA Forest Service internal report. Fort Collins, Colorado, USA: Forest Management Service Center.

Donato, D.C., B.J. Harvey, W.H. Romme, M. Simard, and M.G. Turner. 2013. Bark beetle effects on fuel profiles across a range of stand structures in Douglas-fir forests of greater Yellowstone. Ecological Applications 23 (1): 3-20 https://doi.org/10.1890/12-0772.1.

Fernandes, P.M. 2009. Examining fuel treatment longevity through experimental and simulated surface fire behaviour: A maritime pine case study. Canadian Journal of Forest Research 39 (12): 2529-2535 https://doi.org/10.1139/X09-145.

Fettig, C., R. Borys, and C. Dabney. 2010. Effects of fire and fire surrogate treatments on bark beetle-caused tree mortality in the southern cascades, California. Forest Science 56 (1): 60-73.

Fettig, C.J., K.E. Gibson, A.S. Munson, and J.F. Negrón. 2014. A comment on "management for mountain pine beetle outbreak suppression: Does relevant science support current policy?". Forests 5 (4): 822-826 https://doi.org/10. 3390/ $\$ 5040822$

Fiedler, C.E., K.L. Metlen, and E.K. Dodson. 2010. Restoration treatment effects on stand structure, tree growth, and fire hazard in a ponderosa pine/Douglas-fir forest in Montana. Forest Science 56 (1): 18-31.

Finney, M.A., C.W. McHugh, and I.C. Grenfell. 2005. Stand- and landscape-level effects of prescribed burning on two Arizona wildfires. Canadian Journal of Forest Research 35 (7): 1714-1722 https://doi.org/10.1139/x05-090.

Flannigan, M.D., M.A. Krawchuk, W.J. de Groot, M.B. Wotton, and L.M. Gowman. 2009. Implications of changing climate for global wildland fire. International Journal of Wildland Fire 18 (5): 483-507 https://doi.org/10.1071/WF08187.

Fulé, P.Z., J.E. Crouse, J.P. Roccaforte, and E.L. Kalies. 2012. Do thinning and/or burning treatments in western USA ponderosa or Jeffrey pine-dominated forests help restore natural fire behavior? Forest Ecology and Management 269: 68-81.

Gannon, A., and S. Sontag. 2010. Montana forest insect and disease conditions and program highlights-2010. In USDA Forest Service region 1, Forest health and protection report 11-1. Missoula, Montana: USA.

Grissino-Mayer, H.D., C.M. Gentry, S.Q. Croy, J. Hiatt, B. Osborne, A. Stan, and G. DeWeese Wight. 2006. Fire history of western Montana forested landscapes via tree-ting analyses. Indiana State University Department of geography, geology, and anthropology. Terre Haute, Indiana, USA: Professional Paper No. 23.

Harrington, M.G., E. Noonan-Wright, M. Doherty. 2007. Testing the modeled effectiveness of an operational fuel reduction treatment in a small western Montana interface landscape using two spatial scales. Pages 301-314 in: B.W. Butler, and W. Cook, The fire environment-innovations, management, and policy. USDA Forest Service Proceedings RMRS-P-46CD, Rocky Mountain Research Station, Fort Collins, Colorado, USA.

Hart, S.J., T. Schoennagel, T.T. Veblen, and T.B. Chapman. 2015. Area burned in the western United States is unaffected by recent mountain pine beetle outbreaks. Proceedings of the National Academy of Sciences of the United States of America 112 (14): 4375-4380 https://doi.org/10.1073/pnas.1424037112.

Harvey, B.J., D.C. Donato, W.H. Romme, and M.G. Turner. 2013. Influence of recent bark beetle outbreak on fire severity and postfire tree regeneration in montane Douglas-fir forests. Ecology 94 (11): 2475-2486 https://doi.org/10.1890/13-0188.1.

Hessburg, P.F., D.J. Churchill, A.J. Larson, R.D. Haugo, C. Miller, T.A. Spies, M.P. North N.A. Povak, R.T. Belote, P.H. Singleton, W.L. Gaines, R.E. Keane, G.H. Aplet, S.L. Stephens, P. Morgan, P.A. Bisson, B.E. Rieman, R.B. Salter, and G.H. Reeves. 2015. Restoring fire-prone inland Pacific landscapes: Seven core principles. Landscape Ecology 30: 1805-1835 https://doi.org/10.1007/s10980-015-0218-0.

Hicke, J.A., M.C. Johnson, L.H.D. Jane, and H.K. Preisler. 2012. Effects of bark beetlecaused tree mortality on wildfire. Forest Ecology and Management 271: 81-90.

Hicke, J.A., A.J.H. Meddens, and C.A. Kolden. 2016. Recent tree mortality in the western United States from bark beetles and forest fires. Forest Science 62 (2): 141-153 https://doi.org/10.5849/forsci.15-086.

Hood, S.M., S. Baker, and A. Sala. 2016. Fortifying the forest: Thinning and burning increase resistance to a bark beetle outbreak and promote forest resilience. Ecological Applications 26 (7): 1984-2000 https://doi.org/10.1002/eap.1363.

Jain, T.B., M.A. Battaglia, H.-S. Han, R.T. Graham, C.R. Keyes, J.S. Fried, and J.E. Sandquist. 2012. A comprehensive guide to fuel management practices for dry mixed conifer forests in the northwestern United States. In USDA Forest Service general technical report RMRS-GTR-292. Rocky Mountain Research Station, Fort Collins, Colorado: USA.

Jenkins, M.J., E. Hebertson, W. Page, and C.A. Jorgensen. 2008. Bark beetles, fuels, fires and implications for forest management in the intermountain west. Forest Ecology and Management 254 (1): 16-34 https://doi.org/10.1016/j.foreco.2007.09.045. 
Jenkins, M.J., W.G. Page, E.G. Hebertson, and M.E. Alexander. 2012. Fuels and fire behavior dynamics in bark beetle-attacked forests in western North America and implications for fire management. Forest Ecology and Management 275: 23-34 https://doi.org/10.1016/j.foreco.2012.02.036.

Jenkins, M.J., J.B. Runyon, C.J. Fettig, W.G. Page, and B.J. Bentz. 2014. Interactions among the mountain pine beetle, fires, and fuels. Forest Science 60 (3): 489-501 https://doi.org/10.5849/forsci.13-017.

Johnson, M.C., M.C. Kennedy, and D.L. Peterson. 2011. Simulating fuel treatment effects in dry forests of the western United States: Testing the principles of a fire-safe forest. Canadian Journal of Forest Research 41 (5): 1018-1030 https://doi. org/10.1139/x11-032.

Kane, J.M., J.M. Varner, M.R. Metz, and P.J. van Mantgem. 2017. Characterizing firedisturbance interactions and their potential impacts on tree mortality in western US forests. Forest Ecology and Management 405: 188-199 https:/doi.org/10.1016/j. foreco.2017.09.037.

Keeling, E.G., A. Sala, and T.H. DeLuca. 2006. Effects of fire exclusion on forest structure and composition in unlogged ponderosa pine/Douglas-fir forests. Forest Ecology and Management 237: 418-428 https://doi.org/10.1016/j. foreco.2006.09.064.

Keyes, C.R., and K.L. O'Hara. 2002. Quantifying stand targets for silvicultural prevention of crown fires. Western Journal of Applied Forestry 17 (2): 101-109.

Keyes, C.R., and J.M. Varner. 2006. Pitfalls in the silvicultural treatment of canopy fuels. Fire Manage Today 66: 46-50.

Kolb, T.E., C.J. Fettig, M.P. Ayres, B.J. Bentz, J.A. Hicke, R. Mathiasen, J.E. Stewart, and A.S. Weed. 2016. Observed and anticipated impacts of drought on forest insects and diseases in the United States. Forest Ecology and Management 380: 321-334 https://doi.org/10.1016/j.foreco.2016.04.051.

Larsson, S., R. Oren, R.H. Waring, and J.W. Barrett. 1983. Attacks of mountain pine beetle as related to tree vigor of ponderosa pine. Forest Science 29 (2): 395-402.

MacKinnon, D.P., A.J. Fairchild, and M.S. Fritz. 2007. Mediation analysis. Annual Review of Psychology 58: 593-614 https://doi.org/10.1146/annurev.psych.58. 110405.085542

Martinson, E.J., and P.N. Omi. 2013. Fuel treatments and fire severity: A meta-analysis. Fort Collins, Colorado, USA: USDA Forest Service Research Paper RMRS-RP-103WWW, Rocky Mountain Research Station https://doi.org/10.2737/RMRS-RP-103.

Mclver, J.D., S.L. Stephens, J.K. Agee, J. Barbour, R.E.J. Boerner, C.B. Edminster, K.L. Erickson, K.L. Farris, C.J. Fettig, C.E. Fiedler, S. Haase, S.C. Hart, J.E. Keeley, E.E. Knapp, J.F. Lehmkuhl, J.J. Moghaddas, W. Otrosina, K.W. Outcalt, D.W. Schwilk, C.N. Skinner, T.A. Waldrop, C.P. Weatherspoon, D.A. Yaussy, A. Youngblood, and S. Zack. 2012. Ecological effects of alternative fuel-reduction treatments: Highlights of the National Fire and fire surrogate study (FFS). International Journal of Wildland Fire 22: 63-82 https://doi.org/10.1071/WF11130.

Mclver, J.D., and C.P. Weatherspoon. 2010. On conducting a multisite, multidisciplinary forestry research project: Lessons from the national fire and fire surrogate study. Forest Science 56 (1): 4-17.

Metlen, K.L., and C.E. Fiedler. 2006. Restoration treatment effects on the understory of ponderosa pine/Douglas-fir forests in western Montana, USA. Forest Ecology and Management 222 (1): 355-369 https://doi.org/10.1016/j.foreco.2005.10.037.

Miller, J.D., H.D. Safford, M. Crimmins, and A.E. Thode. 2009. Quantitative evidence for increasing forest fire severity in the Sierra Nevada and southern Cascade Mountains, California and Nevada, USA. Ecosystems 12 (1): 16-32.

Moran, C.J., and M.A. Cochrane. 2012. Do mountain pine beetle outbreaks change the probability of active crown fire in lodgepole pine forests? Comment. Ecology 93 (4): 939-941.

Negrón, J.F., and J.B. Popp. 2004. Probability of ponderosa pine infestation by mountain pine beetle in the Colorado front range. Forest Ecology and Management 191 (1-3): 17-27 https://doi.org/10.1016/j.foreco.2003.10.026

Nelson, K.N., M.G. Turner, W.H. Romme, and D.B. Tinker. 2017. Simulated fire behaviour in young, postfire lodgepole pine forests. International. International Journal of Wildland Fire 26 (10): 852-865 https://doi.org/10.1071/WF16226.

Nimlos TJ (1986). Soils of Lubrecht experimental Forest. Montana Forest and conservation Experiment Station, miscellaneous publication no. 44, Missoula, Montana, USA.

Noonan-Wright, E.K., N.M. Vaillant, and A.L. Reiner. 2014. The effectiveness and limitations of fuel modeling using the fire and fuels extension to the Forest vegetation simulator. Forest Science 60 (2): 231-240 https://doi.org/10.5849/forsci.12-062.

Page, W.G., and M.J. Jenkins. 2007. Mountain pine beetle-induced changes to selected lodgepole pine fuel complexes within the intermountain region. Forest Science 53 (4): 507-518.

Parsons, D.J., and S.H. DeBenedetti. 1979. Impact of fire suppression on a mixedconifer forest. Forest Ecology and Management 2: 21-33 https://doi.org/10. 1016/0378-1127(79)90034-3.
Pfister, R.D., B.L. Kovalchik, S.F. Arno, and R.C. Presby. 1977. Forest habitat types of Montana. In USDA Forest Service general technical report INT-GTR-34. Intermountain Research Station, Ogden, Utah: USA.

Pinheiro J, Bates D, DebRoy S, R Core Team. 2016. NIme: Linear and nonlinear mixed effects models. http://cran.r-project.org/package=nlme. Accessed 9 Oct 2018.

Raffa, K.F., B.H. Aukema, B.J. Bentz, A.L. Carroll, J.A. Hicke, M.G. Turner, and W.H. Romme. 2008. Cross-scale drivers of natural disturbances prone to anthropogenic amplification: The dynamics of bark beetle eruptions. BiosSience 58 (6): 501-517 https://doi.org/10.1641/B580607.

Rebain, S. 2010. The fire and fuels extension to the Forest vegetation simulator: Updated model documentation. Fort Collins Available online at: USDA Forest Service, Forest Management Service Center http://www.fs.fed.us/fmsc/ftp/fvs/ docs/gtr/FFEguide.pdf.

Reineke, L.H. 1933. Perfecting a stand-density index for even-aged forests. Journal of Agricultural Research 46: 627-638.

Reinhardt, E.D., R.E. Keane, D.E. Calkin, and J.D. Cohen. 2008. Objectives and considerations for wildland fuel treatment in forested ecosystems of the interior western United States. Forest Ecology and Management 256 (12): 1997-2006 https://doi.org/10.1016/j.foreco.2008.09.016.

Savage, M., and J. Nystrom Mast. 2005. How resilient are southwestern ponderosa pine forests after crown fires? Canadian Journal of Forest Research 35 (4): 967-977 https://doi.org/10.1139/X05-028.

Schoennagel, T., T.T. Veblen, J.F. Negron, and J.M. Smith. 2012. Effects of mountain pine beetle on fuels and expected fire behavior in lodgepole pine forests, Colorado, USA. PLoS One 7 (1): 1-14 https://doi.org/10.1371/journal.pone.0030002.

Scott, J.H.E.D. Reinhardt. 2001. Assessing crown fire potential by linking models of surface and crown fire behavior. In USDA Forest Service research paper RMRSRP-29. Rocky Mountain Research Station, Fort Collins, Colorado: USA.

Sieg, C.H., R.R. Linn, F. Pimont, C.M. Hoffman, J.D. McMillin, J. Winterkamp, and L.S. Baggett. 2017. Fires following bark beetles: Factors controlling severity and disturbance interactions in ponderosa pine. Fire Ecology 13 (3): 1-23 https:// doi.org/10.4996/fireecology.130300123.

Simard, M., W.H. Romme, J.M. Griffin, and M.G. Turner. 2011. Do mountain pine beetle outbreaks change the probability of active crown fire in lodgepole pine forests? Ecological Monographs 81 (1): 3-24 https://doi.org/10.1890/10-1176.1.

Six, D.L., E. Biber, and E. Long. 2014. Management for mountain pine beetle outbreak suppression: Does relevant science support current policy? Forests 5 (1): 103-133 https://doi.org/10.3390/f5010103.

Six, D.L., and K. Skov. 2009. Response of bark beetles and their natural enemies to fire and fire surrogate treatments in mixed-conifer forests in western Montana. Forest Ecology and Management 258: 761-772 https://doi.org/10.1016/j.foreco. 2009.05.016.

Stephens, S.L., B.M. Collins, and G. Roller. 2012. Fuel treatment longevity in a Sierra Nevada mixed conifer forest. Forest Ecology and Management 285: 204-212 https://doi.org/10.1016/j.foreco.2012.08.030.

Stephens, S.L., and J.J. Moghaddas. 2005. Experimental fuel treatment impacts on forest structure, potential fire behavior, and predicted tree mortality in a California mixed conifer forest. Forest Ecology and Management 215: 21-36 https://doi.org/10.1016/j.foreco.2005.03.070.

Stephens, S.L., J.J. Moghaddas, C.B. Edminster, C.E. Fiedler, S.M. Haase, M.G. Harrington, J.E. Keeley, E.E. Knapp, J.D. Mclver, K. Metlen, C.N. Skinner, and A. Youngblood. 2009. Fire treatment effects on vegetation structure, fuels, and potential fire severity in western US forests. Ecological Applications 19 (2): 305-320 https://doi.org/10.1890/07-1755.1.

Tinkham, W., C. Hoffman, S. Ex, M. Battaglia, and J. Saralecos. 2016. Ponderosa pine forest restoration treatment longevity: Implications of regeneration on fire hazard. Forests 7 (7): 137 https://doi.org/10.3390/f7070137.

US Forest Service. 2005. Forest inventory and analysis National Core Field Guide Volume I: Field data collection procedures for phase 2 plots. <https://www. fia.fs.fed.us/library/field-guides-methods-proc/>. Accessed 9 Oct 2018.

Wallin, K.F., T.E. Kolb, K.R. Skov, and M.R. Wagner. 2003. Effects of crown scorch on ponderosa pine resistance to bark beetles in northern Arizona. Environmental Entomology 32 (3): 652-661 https://doi.org/10.1603/0046-225X-32.3.652.

Weatherspoon, C.P. 2000. A long-term national study of the consequences of fire and fire surrogate treatments. In Proceedings of the joint fire science conference and workshop_Crossing the millenium: Integrating spatial technologies and ecological principles for a new age in fire management, ed. L.F. Neuenschwander and K.C. Ryan, 117-126. Moscow: University of Idaho Press.

Westerling, A.L., H.G. Hidalgo, D.R. Cayan, and T.W. Swetnam. 2006. Warming and earlier spring increase western US forest wildfire activity. Science 313: 940-943 https://doi.org/10.1126/science.1128834. 